\title{
W kierunku pełni. 0 literaturze światowej na studiach germanistycznych
}

\section{Aiming at completeness. About world literature on Germanic philology}

\section{Wiktorii de Sherbroecke}

\section{Streszczenie:}

Artykuł podejmuje rozważania dotyczące zajęć z literatury światowej na filologii germańskiej. Wskazuje się $\mathrm{w}$ nim na korzyści płynące $\mathrm{z}$ rewitalizacji tego przedmiotu w germanistycznej dydaktyce. Stanowiąc wyłącznie kadłubową i otwartą wobec dyskusji propozycję, tekst porusza ponadto niektóre istotne kwestie praktyczne dotyczące formalnego i treściowego ukształtowania kursu literatury światowej w ramach studiów germanistycznych.

Słowa kluczowe: filologia germańska, literatura światowa, dydaktyka literatury

\begin{abstract}
:
The article contains a proposal for the formation of a world literature course in Germanic philology studies. It discusses the didactic aspects of the course and its contents. The whole proposal can be modified in various ways, depending on particular didactic needs. Nevertheless, the article also stresses the general necessity of introduction of such courses on Germanic philology, in view of the contemporary social and professional challenges.
\end{abstract}

Keywords: Germanic philology, world literature, teaching of literature 
Szymon Gębuś - W kierunku pełni. O literaturze światowej...

Zagubiony na jałowych pustkowiach własnej śmiertelności, nie mogq̨c znaleźć punktu oparcia w królestwie nauki, na wewnątrzkomórkowych ścieżkach molekularnych i nieskończonych zakrętach statystyk przetrwania, znów zwróciłem się ku literaturze. Czytałem Oddział chorych na raka Sołżenicyna, Nieszczęsnych B. S. Jonhsona, Śmierć Iwana Iljicza Tołstoja, Mind and Cosmos Nagela, Woolf, Kafkę, Montaigne'a, Frosta, Greville'a, wspomnienia chorych na raka... Krótko mówiq̨c wszystko, co kiedykolwiek napisano na temat śmiertelności. Potrzebowałem słownika, który pozwoliłby mi zrozumieć śmierć, znaleźć sposób na ponowne zdefiniowanie własnej tożsamości i ruszenie z miejsca. Przywilej bezpośredniego doświadczenia odwiódł mnie od literatury i pracy akademickiej, a mimo to teraz czułem, że muszę przetłumaczyć własne doświadczenia na język, by móc je pojać. W podobny sposób Hemingway opisywał własny proces - gromadzenia bogatych doświadczeń i wycofywania się, aby je kontemplować i o nich pisać. Wiedziałem, że nie obejdę się bez słów, jeśli chcę poczynić jakiekolwiek postępy.

Paul Kalanithi, Jeszcze jeden oddech

\section{Dlaczego literatura światowa?}

Kursy literatury powszechnej/światowej ${ }^{1}$ na krajowych filologiach germańskich popadły w niełaskę już dawno², w germanistycznym środowisku trudno zaś dostrzec skłonność do bodaj zastanowienia się nad renesansem tego cennego przedmiotu jako powszechnie na nich funkcjonujących, umiejętnie wkomponowanych w curricula i rozważnie skorelowanych z całością „programu literackiego” zajęć ${ }^{3}$. Można nad tym swoistym zubożeniem filologii ubolewać; wydaje się jednak, że przemyślenie ogólnokierunkowej rewitalizacji takich zajęć jest pragmatycznie uzasadnione wymogiem chwili. Nie tylko z niekwestionowanej przyczyny, że literatura światowa merytorycznie znakomicie ożywiłaby "germanocentryczny" dyskurs literacki, umieszczając go w szerszych, relatywizujących konstelacjach i tworząc z nim wza-

\footnotetext{
1 Używam określenia „literatura powszechna/światowa”, którą rozumiem przedmiotowo, nie zaś „komparatystyka”, którą pojmuję raczej jako metodę badawczą.

2 Miałem jeszcze okazję uczestniczyć w wykładach z „literatury powszechnej”, prowadzonej na wrocławskiej germanistyce w semestrze zimowym roku 1994/1995. Takich zajęć dawno już w tej placówce zaniechano.

3 Jako zbyt mało istotne pomijam tu okazjonalne zajęcia opcjonalne, praktykowane niekiedy na krajowych filologiach.
} 
jemne, atrakcyjne poznawczo parantele, co przy sprawnej realizacji dydaktycznej poskutkowałoby m. in. dogłębniejszym i wszechstronniejszym zrozumieniem przez studentów także utworów niemieckojęzycznych. Przede wszystkim jednak wydaje się, że filologie powinny teraz energicznie poszukiwać modeli szerszego i pełniejszego kształcenia, lepiej przygotowującego adeptów do pomyślnego funkcjonowania na krajowym i globalnym rynku wiedzy i pracy; powinny zatem sformułować swoistą filologiczną odpowiedź na realia „płynnej nowoczesności" w czasach globalizacji, rywalizacji, transdyscyplinarności, umiędzynarodowienia kultury, konfrontacji cywilizacyjnych ${ }^{4}$ i dogodnych możliwości wykorzystywania bezbrzeżnych, multijęzykowych zasobów wiedzy i informacji. W jakimś, niechby i niewielkim stopniu, taką możliwość z pewnością dawałyby m. in. (zrestytuowane) zajęcia $\mathrm{z}$ literatury powszechnej, połączone np. $\mathrm{z}$ dążeniem do wszechstronniejszego kształcenia językowego studentów 5 .

\footnotetext{
40 których pisał S. P. Huntington w głośnym eseju Wojna cywilizacji?, „Res Publica Nowa" 1994, nr 2(65), s. 69-79. Cennym i ambitnym (np. semestralnym) ćwiczeniem na zajęciach z literatury światowej mogłaby być próba szerokiego spojrzenia na współczesne procesy historycznoliterackie w odniesieniu do podstawowych tez tego tekstu, mówiącego o „cywilizacyjnym” wzorcu konfliktów globalnych po upadku bloku komunistycznego (różnice między cywilizacjami mają obecnie znaczenie podstawowe; „zmniejszający się” świat wymusza częstsze i bardziej zróżnicowane interakcje międzyludzkie, uświadamiające ich uczestnikom odmienność poszczególnych cywilizacji; religie jako baza tożsamości oraz tożsamościowe spoiwo transcendujące granice państwowe; obecny szczyt potęgi Okcydentu versus powrót do korzeni i roszczenia cywilizacji niezachodnich; różnice kulturowe i cywilizacyjne jako bardziej znaczące i trudniejsze do pogodzenia niż różnice polityczne i ekonomiczne; ekonomiczny regionalizm jako m. in. wzmocnienie świadomości cywilizacyjnej). Prowadzący musiałby skupić uwagę na odpowiednich autorach oraz stosownych tekstach. Ich analizy powinny uwzględniać konteksty historyczne i cywilizacyjne, wydźwięk polityczny i ideologiczny, charakterystykę recepcji oraz aspekty socjologiczno-literackie.

${ }^{5}$ Co stanowiłoby zupełnie osobny przedmiot rozważań. Odpowiednie przygotowanie językowe warunkuje wszakże rzetelne studia nad literaturą światową według przedstawionej tu wizji - konieczne choćby po to, by móc sprawnie pożytkować proponowane tu prace anglo- czy hiszpańskojęzyczne. Studenci germanistyki mogliby ewentualnie korzystać $\mathrm{z}$ nich $\mathrm{w}$ oryginale, sam też prowadzący mógłby przygotowywać zajęcia na ich podstawie, referując ich treść czy stosując zalecane tam ćwiczenia etc.
} 
Szymon Gębuś - W kierunku pełni. O literaturze światowej...

Inny niż zmierzanie do bardziej uniwersalnego kształcenia trend dydaktycznej ewolucji studiów filologicznych trudno sobie w tej chwili nawet wyobrazić; wydaje się zresztą, że już ekspandują one coraz wyraźniej w tym kierunku, bo tak można interpretować np. pojawienie się filologicznych kierunków dwujęzycznych, komparatystycznych czy też plany zorganizowania na uniwersytecie w Poznaniu studiów magisterskich o nazwie „literatury świata” ze specyficzną strukturą organizacyjno-dydaktyczną (konieczność władania przez kandydatów minimum dwoma językami obcymi w tym obowiązkowo angielskim, możliwość podjęcia nauki na bazie licencjatu np. z germanistyki oraz prowadzenie zajęć przez specjalistów różnych filologii) ${ }^{6}$. Można zatem zakładać, że tego rodzaju wewnętrzna, „wzbogacająca dehermetyzacja" studiów filologicznych będzie współkształtowała ich tożsamość w dłuższej perspektywie i z tego m. in. powodu, pojawianie się wszelkich „inter-” i „multifilologicznych” rozwiązań należy przyjmować raczej z życzliwością i zainteresowanym oczekiwaniem.

Zarysowe zaś choćby rozważania nad treściowym i formalnym ukształtowaniem tak skromnego „interfilologicznego” projektu dydaktycznego jak kurs literatury światowej na studiach germanistycznych wymagałyby przynajmniej wstępnych odpowiedzi na kilka dalszych, zasadniczych dla tematu pytań. Mianowicie:

\section{Czego student powinien się nauczyć?}

Wyjściowe pytanie, które zorientuje nasze poszukiwania także w zakresie metodyki zajęć i doboru odpowiednich dla nich tekstów; odpowiedź zaś na nie można zgrupować wokół trzech integralnie połączonych punktów. Zdobycie zatem przez studenta pewnego zasobu wiedzy faktograficznej dotyczącej omawianych treści to poniekąd naturalna nieodzowność, związana zgoła immanentnie z nadrzędnym rocznym/semestralnym tematem zajęć (zwanym tu ramą

\footnotetext{
${ }^{6}$ Niedoszłe ostatecznie do skutku otwarcie tego kierunku planowano na jesień 2017 roku. Zob. stronę dla kandydatów: https://rekrutacja.amu.edu.pl/Strona/Kie runki/Szczegoly/Filologia-specjalnosc-literaturyswiata,671 [dostęp: 10.10.2017].
} 
tematyczną). Tą z kolei można ukształtować dość dowolnie, np. jako chronologiczny przegląd literatury światowej w pierwszym semestrze a w drugim - dogłębną analizę wybranych dzieł; lub w pierwszym semestrze - fikcja historyczna, w drugim - postmodernizm, czy też semestr/rok o wybranym spektrum tematycznym, np. „podstęp i kłamstwo"7 czy „szaleństwa i aberracje” w literaturze, czy twórczość noblistów ${ }^{8}$ itd. Można też odchylić dyskurs w stronę zagadnień socjokulturowych, np. w temacie „literatura światowa a popkultura” itp., bądź uprawiając kulturowo-egzystencjalną interpretację arcydzieł literatury ${ }^{9}$ itd. Niezależnie wszak od danej ramy (meta)tematycznej i poznawanych $\mathrm{w}$ jej obrębie tekstów, student powinien ponadto wstępnie zaznajomić się ze współczesnymi debatami toczonymi wokół przedmiotu literatury światowej ${ }^{10}$, poznać postacie naukowe i badania liderów dyscypliny (Bloom, Damrosch, Casanova czy Moretti), orientować

\footnotetext{
7 Pomocą usłuży tu: P. von Matt, Intryga. Teoria i praktyka podstępu w literaturze, Warszawa 2009, z bardzo ciekawymi nawiązaniami do literatury niemieckojęzycznej.

${ }^{8}$ Studenci mogą pobawić się literaturą noblowską, np. układając i uzasadniając alternatywną listę noblistów, od zarania lub np. w ostatnim dziesięcioleciu, co może wywołać dyskusję o historii nagrody, kulisach jej przyznawania, itp. Wgłębieniu się w nią przysłuży się książka K. Espmarka Der Nobelpreis für Literatur. Prinzipien und Bewertungen hinter den Entscheidungen, Getynga 1988. Nieco płytszą ale błyskotliwiej napisaną, znacznie aktualniejszą i ciekawiej formującą treść (problemowo, achronologicznie) jest pozycja D. Cartera How to Win the Nobel Prize in Literature. A Handbook for the Would-be Laureate, Londyn 2012, swoją drogą notorycznie acz z korzyścią dla treści odwołująca się do dzieła Espmarka. Świetnym zaś ćwiczeniem stylistycznym byłoby np. napisanie przez studenta szeroko i wszechstronnie uzasadnionej (biografia, ranga artystyczna, recepcja międzynarodowa, tłumaczenia na języki obce, tematyka twórczości etc.) rekomendacji dla jakiegoś pisarza, adresowanej do Akademii Szwedzkiej, czy dyskusja nad buntowniczym artykułem W. Łysiaka Cyrk Nobla literackiego, „Uważam Rze” 2012, nr 39(86), s. 42-55; do tego np. lektura „noblowskiej" eseistyki G. G. Márqueza ze zbiorów Morze utraconych opowiadań i inne felietony, Warszawa 2000 oraz Nie wygłoszę tu mowy, Warszawa 2011.

${ }^{9}$ Zob. informacje o takim kursie na stronie Uniwersytetu Warszawskiego: https://www.uo.uw.edu.pl/kurs/3108 [dostęp: 10.10.2017].

$10 \mathrm{~W}$ czym pomogą np. przyczynki z czasopisma „Teksty Drugie. Teoria literatury. Krytyka. Interpretacja" 2014, nr 4, np. Literatura światowa i jej figury P. Czaplińskiego (s. 13-40) czy Między komparatystyka literacka a literatura światowa A. F. Koli (s. 4163).
} 
Szymon Gębuś - W kierunku pełni. O literaturze światowej...

się w pojęciowej „metafizyce” przedmiotu ${ }^{11} \mathrm{i}$ jego interdyscyplinarnych odniesieniach. Powinien też zaznajomić się z krajowymi i światowymi czasopismami tematycznymi oraz wiedzieć, do których wartościowych zasobów odnośnej wiedzy historycznoliterackiej może $\mathrm{w}$ razie potrzeby sięgnąć.

Uprzywilejowywanie wszak pamięciowej kumulacji wiedzy dawno już stało się démodé; bardziej powinno nam zależeć na wykształceniu u studentów pewnego zestawu umiejętności operacyjnych, przyswojeniu przez nich określonej metodyki postępowania z tekstami, popartej nieodzowną i przykrojoną do owej metodyki wiedzą. Wszystko to $\mathrm{w}$ celu m. in. zwiększenia ich możliwości analitycznego odczytywania oraz kompetentnego i wszechstronnego rozumienia (zagranicznych) utworów literackich. Student musi po prostu więcej „widzieć” w tych utworach; trzeba mu więc pomóc rozbudować oraz ustrukturyzować (może też ustandaryzować) drogi jego rozumowania, rozwijając jego odnośną „wiedzę proceduralną” oraz dociekliwość i kreatywność w obchodzeniu się z nimi.

Nie zdołam tutaj rozwijająco omówić wszystkich odnośnych koncepcji dydaktycznych, stąd odosobniony przykład. Studentowi potrzebna byłaby nie tyle np. dosłowna, pamięciowa znajomość twierdzeń poszczególnych szkół literaturoznawczych czy partykularyzmów badawczych, co raczej umiejętność ich zastosowania w praktyce analizy i rozumienia tekstu. Dobrze więc, jeśli będzie wiedział np. że „rosyjscy formaliści odróżnili sjużet od fabuły” i jak te ustalenia wypadają na tle innych koncepcji, powinien jednak przede wszystkim umieć wskazać obie te sfery na konkretnych przykładach z tekstu danego utworu. Jeżeli dowie się o „obiektywnym korelacie” (odpowiedniku przedmiotowym) Eliota to powinien go owszem, umieć zdefiniować, ale też wskazać jego przykłady w różnych tekstach i ewentualnie także samodzielnie stworzyć krótki utwór z najprostszym choćby ta-

\footnotetext{
11 Począwszy od zrozumienia pierwotnej, goethańskiej koncepcji Weltliteratur, na temat której klarownie pisał D. Lamping w zwięzłej pracy Die Idee der Weltliteratur. Ein Konzept Goethes und seine Karriere, Stuttgart 2010. Zob. też poprzedni przypis.
} 
kim chwytem ${ }^{12}$. Jeżeli przeczyta u Escarpita o „podatności na zdradę” dzieła literackiego, a u Sławińskiego o rozróżnieniu między jego „produktywnością" a „oryginalnością”, to powinien umieć te idee zdefiniować, scharakteryzować na przykładach i wyjaśnić różnice/podobieństwa między nimi. Jeżeli pozna założenia dekonstrukcjonizmu, to niech odpowie na zadawane przezeń pytania (zob. poniżej) i spróbuje samodzielnej dekonstrukcji przykładowego utworu ${ }^{13}$. Teorie literackie można zaś traktować głównie jako środki rozumienia tekstów, a jako takie, godne byłyby polecenia przede wszystkim $\mathrm{w}$ postaci sformułowanych i gotowych do zastosowania pytań, np.:

1. Związki z jakimi tekstami można znaleźć w utworze? Na czym polega jego inkoherencja? Jakie niespodziewane znaczenia ujawnia? (dekonstrukcjonizm).

2. Jakie tzw. praktyki symboliczne pojawiają się w tekście? Jakie zachowania kulturowe są w nim faworyzowane? (kulturowa teoria literatury).

3. Którą rasę reprezentuje bohater? Jaki jest jego pozycja wobec innych kultur? Jakie jest miejsce jego kultury w kontekście światowym? (postkolonializm).

I tak dalej. Teorie zatem czy rozumienia (także psychologiczne, socjologiczne, psychoanalityczne...) mogą być zatem pojmowane jako swoiste metodologie, języki interpretacji umożliwiające różnostronne

\footnotetext{
12 Może w tym pomóc np. strona internetowa Ingrid Sundberg: http://ingridsund berg.com/2013/05/14/what-is-the-objective-correlative/ [dostęp: 10.10.2017], gdzie znajdujemy takie ćwiczenie: „Write a scene in which a man describes a body of water (i.e. ocean, river, pond, etc.) after having just murdered someone. However, the man can never mention the murder or any of the details related to the murder".

${ }^{13}$ Kilka anglojęzycznych stron z przykładowymi dekonstrukcjami krótkich tekstów: 1. An Exercise in Literary Deconstruction: Frankenstein by Mary Shelley, https://drconway.wordpress.com/2010/02/02/an-exercise-in-literary-deconstruction-frankenstein-by-mary-shelley/ [dostęp: 10.10.2017]; 2. An Exercise in Deconstruction - William Blake's „The Little Black Boy”, https://genius.com/A-b-schmidtan-exercise-in-deconstruction-william-blakes-the-little-black-boy-annotated [dostęp: 10.10.2017]; 3. Julia's Deconstructive Analysis of The Road Not Taken, http://scan lon295f13.umwblogs.org/2013/10/08/julias-deconstructive-analysis-of-the-road-nottaken [dostęp: 10.10.2017].
} 
Szymon Gębuś - W kierunku pełni. O literaturze światowej...

oglądy tekstów, zaś poznanie tychże teorii jako wprowadzenie do praktyk analitycznych i interpretujących, służących lepszemu rozumieniu tychże tekstów i odkrywaniu ich mulitwalencji. Młody człowiek powinien więc umieć patrzeć na treści literackie na różne sposoby i opanować podstawowe „różnoteoretyczne” praktyki analityczne ${ }^{14}$ na solidnym poziomie świadomej kompetencji15.

Inną jeszcze umiejętnością (to trzeci punkt, połączony wszak z drugim) jest wykroczenie poza bezpośredni kontakt z samym utworem i postrzeganie go w dynamicznych kontekstach kulturowych. Dobrze byłoby więc, gdyby student np. poznał filmową czy teatralną historię danego dzieła, umiał zdobyć wiedzę na temat chronologicznych transformacji relacji krytycznych (czy np. ideologicznych) wobec niego, poznał jego „przyległości i fakty go poprzedzające” (Antoine Compa-

${ }^{14}$ Oczywiście, że tego typu praktyczne ćwiczenia można prowadzić także w ramach odpowiednio zmodyfikowanych programowo zajęć z literaturoznawstwa czy historii literatury niemieckiej, niezależnie od tego czy w ramach „bloku literaturoznawczego" towarzyszyłby im kurs literatury światowej. Takie ewentualności zależałyby od przyjętej odnośnie tej kwestii koncepcji oraz sensu (pożytku z) jej realizacji w określonej dydaktycznej dialektyce, w obrębie wszystkich zajęć historycznoliterackich/literaturoznawczych. Między innymi z tego powodu, niniejszy szkic stanowi wyłącznie pewną wstępną propozycję, bardziej próbę poszukiwania rozwiązań niż gotową i niereformowalną receptę, gotową na wcielenie bez względu na kontekst dydaktyczny. Wydaje się jednak, że rozbudowany kurs literatury światowej szczególnie sprzyjałby nauce praktycznych umiejętności literaturoznawczych, analitycznych i interpretacyjnych, ze względu na sporo jednak większą (niż np. na zajęciach z historii literatury niemieckiej) dowolność w doborze tekstów, kształtowaniu programu nauczania i tematycznym ukierunkowaniu zajęć. Obszerny, roczny czy dwuletni, kurs literatury światowej mógłby przy takim podejściu np. wchłonąć zajęcia z teoretycznego literaturoznawstwa.

15 Trzecie stadium w „czterostopniowej skali kompetencji” (ang. Four Stages of Competence); koncepcji powstałej w latach siedemdziesiątych $\mathrm{XX}$ wieku, przypisywanej amerykańskiemu psychologowi Noelowi Burchowi, niekiedy zaś (błędnie) Abrahamowi Masłowowi. Skala opisuje kolejne fazy nabywania umiejętności (uczenia się): nieświadoma niekompetencja - świadoma niekompetencja - świadoma kompetencja - nieświadoma kompetencja (ang. unconscious incompetence - conscious incompetence - conscious competence - unconscious competence), gdzie ostatnie stadium określa zdolność płynnego a bezrefleksyjnego wykonywania, choćby kompleksowej, czynności. W przypadku literatury, umiejętność jej poprawnej analizy wspomaganej jawnym myślowym wysiłkiem (świadomą kompetencję) można uważać za wystarczającą i zarazem pożądaną. 
gnon) ${ }^{16}$ i potrafił o nie $\mathrm{z}$ uzasadnieniem pytać oraz samodzielnie poszukiwać odpowiedzi, umiał ulokowywać teksty literackie wśród dyskursów estetycznych i filozoficznych, kulturowych, historycznoliterackich zarazem poznając je, przynajmniej w podstawowym zakresie, przy każdym poznawanym utworze. Biorąc najprostsze przykłady: jeśli Jorge Luis Borges to jego tłumaczenia utworów Franza Kafki, jeśli Wolter to Émilie du Châtelet, jeśli Wirginia Woolf to grupa Bloomsbury, jeśli Dziennik szaleńca Lu Xuna to Pamiętnik wariata Mikołaja Gogola oraz freudyzm, paranoja, „manifest kanibalistyczny” Oswalda de Andrade i europejski modernizm ${ }^{17}$, jeśli księga Hioba to babiloński Dialog o ludzkim nieszczęściu ${ }^{18}$ i tak dalej. Czyli, niczym w dyskursie kulturowym, widzieć wokół tekstu jego istotne odniesienia i zależności językowe, społeczne, intertekstualne, personalne, ideologiczne... W takich właśnie kontekstach prezentowali pisarstwo profesorowie Harvardu David Damrosch i Martin Puchner, gdy wiosną 2017 roku miałem okazję uczestniczyć w ich, prowadzonych online, wykładach z literatury światowej. Do korpusu omówionych autorów/tekstów (zapewne też przewidującego geograficzno-kulturowy rozrzut słuchaczy) zaliczali się:

1. Johann Wolfgang von Goethe,

2. Gilgamesz,

3. Homer, Odyseja,

4. Księga tysiq̨ca i jednej nocy,

5. Wolter, Kandyd,

6. Orhan Pamuk, Nazywam się Czerwień,

7. Wole Soyinka, Death and the King's Horseman (dramat),

8. Lu Xun, Dziennik szaleńca,

9. Eileen Chang19,

\footnotetext{
${ }^{16}$ A. Compagnon, Demon teorii. Literatura a zdrowy rozsq̨dek, Gdańsk 2010, s. 183.

17 Lu Xun urodził się kilka miesięcy przed Jamesem Joyce'em i Virginią Woolf.

18 Ten tekst ukazał się po polsku w: K. Łyczkowska, Babilońska literatura mądrości, Warszawa 1998, s. 58-69.

19 Pisarka chińska (1920-1995), autorka powieści, opowiadań i licznych scenariuszy filmowych. W 1955 roku wyjechała do Stanów Zjednoczonych, gdzie mieszkała do
} 
Szymon Gębuś - W kierunku pełni. O literaturze światowej...

10. Murasaki Shikibu, Genji monogatari ${ }^{20}$,

11. Jorge Luis Borges, Fikcje,

12. Salman Rushdie,

13. Jhumpa Lahiri ${ }^{21}$,

14. Luís Vaz de Camões, Luzytanie.

Harwardzcy uczeni, atrakcyjnie prowadząc zajęcia w postaci dialogu (plus rozmowy z okazjonalnie zapraszanymi specjalistami, głównie z uniwersytetu Harvarda), kompetentnie wyławiali i zajmująco przedstawiali istotne uwarunkowania przedstawianej twórczości; podobne prezentowanie kursowych treści wydaje się zgoła wzorcowe.

Sumując, student powinien:

1) zdobyć odnośną wiedzę deklaratywną, tzn. zarówno w zakresie ramy tematycznej (omawianych utworów), dyskursów o literaturze światowej oraz analizy i interpretacji tekstu (punkty b i c),

2) poznać techniki analizy tekstów (ich wewnętrznej organizacji jednostek językowych, kompozycyjnych itd.) i umieć je zastosować, opanować też pewien asortyment procedur/taktyk interpretacyjnych, zdobywając zdolność do pewnego określenia semantyki dzieła i zidentyfikowania jego „infrasensów”, zarazem do wykreowywania z niego Cullerowskich „nadrozumień”22, powinien zatem zdobyć odnośną wiedzę „proceduralną” na poziomie świadomej kompetencji,

3) widzieć proces historycznoliteracki i jego elementy w sieci różnorako zmiennych zależności, okoliczności, rozumień i kontekstów,

końca życia. W Polsce ukazał się jej zbiór opowiadań Miłość jak pole bitwy (2008); z tego tomu pochodzi, wydane też osobno, Ostrożnie, pożądanie (2008) - opowiadanie, które posłużyło za kanwę filmu Anga Lee pod tym samym tytułem.

${ }^{20}$ Japońska opowieść z XI wieku, nieprzełożona dotąd w całości na polski. Tytuł podanego w aneksie angielskiego przekładu to The Tale of Genji, co można oddać jako Opowieść o księciu Genji.

21 Prozaiczka bengalskiego pochodzenia, urodzona w 1967 roku w Londynie, od wczesnego dzieciństwa zamieszkała w USA. Pochłania ją problematyka indyjskiej emigracji, obecna w Tłumaczu chorób (wydanie polskie 2010), Imienniku (2007), Nieoswojonej ziemi (2010) i Zagubionych wśród hiacyntów (2015).

${ }^{22}$ Zob. wywody J. Cullera w: U. Eco, R. Rorty, J. Culler, C. Brooke-Rose, Interpretacja i nadinterpretacja, Kraków 2008, s. 124-139. 
identyfikować je i wszechstronnie rozumieć ich presję na utwór, czytelników i autora, umieć też samodzielnie odnajdywać i krytycznie zgłębiać istotne $\mathrm{z}$ nich ${ }^{23}$.

Mowa o określonych celach, ponownie natomiast podkreślmy, że odrębną sprawę stanowi przybranie treściowe, w którym zostaną one realizowane. Treści nauczania (nasze „ramy tematyczne”) zasługują bowiem na zainteresowanie, o ile w ich dydaktyce uwzględni się konieczność osiągnięcia przez studenta wymienionych celów; innymi słowy, ramy te powinny być realizowane tak by oferować ku temu sposobność. Powyższe zaś dydaktyczne priorytety stanowią pewną bazę umiejętności, która przecież u studentów często rażąco wręcz kuleje, a bez opanowania której nie będzie można mówić o kompetentnym rozumieniu literatury - stanowiącym tedy jakby nadrzędne dążenie kursu24.

Kolejnym byłoby zaś osiągnięcie przez studenta pewnej fundamentalnie ważnej świadomości: otóż powinien on skończyć kurs z przekonaniem „jak łatwo jest dobrze rozumieć literaturę" i to, czy będzie ją rozumiał bardzo dobrze, zależy głównie od jego dalszych w tej kwestii decyzji.

23 Takie postulaty odnośnie zespołu docelowych umiejętności zbliżają je do sugestii E. Turkowskiej, zawartych $\mathrm{w}$ jej artykule Integracyjny model kształcenia literackiego i językowego na kursie literatury niemieckojęzycznej, [w:] E. Turkowska (red.), Kształcenie nauczycieli języków obcych, Radom 2013. s. 126-138. Autorka opatruje te umiejętności hasłem „kompetencji literackiej”, na którą składają się poszczególne kompetencje cząstkowe jak: „receptywna”, „produktywna” czy „uczestnictwo w życiu literackim" i która pozostaje w ścisłym związku z tzw. kompetencją "czytelniczą" czy „medialną". Pomijając ten fakt, trzeba także zgodzić się z uwagą autorki, że „(..) kształcenie literackie jest procesem wieloletnim i wielostronnym, dalece wykraczającym poza interpretację tekstu literackiego i wiedzę o epokach, do których to aspektów niekiedy się je sprowadza" (s. 130).

24 Tak ukierunkowane zajęcia zapewne ułatwiłyby studentom także dobycie szeregu umiejętności przydatnych w pracy naukowej. 
Szymon Gębuś - W kierunku pełni. O literaturze światowej...

\section{Jakimi metodami?}

Określenie celów dydaktycznych implikuje nieodzowność określenia strategii, metod oraz technik ich skutecznego osiągania. Najwygodniejszą zatem ogólną strukturą dla zajęć wydaje się z pewnością konwersatorium, jako najpojemniejsze metodycznie i ułatwiające różnorakie interakcje dydaktyczne w elastycznych proporcjach. Konkretna zaś metoda lub metody (jako pewien kompozyt metodyczny) są wskazane lub akceptowalne pod warunkiem efektywności i możliwości zastosowania $\mathrm{w}$ jego ramach. Przykładowo w konwersatorium można z powodzeniem wkomponować tzw. handlungsorientierter Literaturunterricht („zajęcia zorientowane na działanie”), choć jej poszczególne elementy muszą uwzględniać nadrzędne cele zajęć i poziom uniwersytecki; zadania obejmowałyby więc w tym przypadku np. tworzenie rozprawek, interpretacji, recenzji, dyskusje wspierane przygotowanymi referatami, tworzenie multimedialnych prezentacji, różnorodnych parafraz analizowanego tekstu, ćwiczebne przygotowanie np. wywiadu z autorem itp. Szczegółowe prace poświęciła tej koncepcji dydaktycznej Ewa Turkowska25, apologizując odejście od anachronicznej dominacji nauczyciela w stronę koncentracji na aktywności uczniów/studentów, dzięki której mogą oni rozszerzyć swoje doświadczenie tekstu poprzez rozmaite twórcze interakcje z nim, co zarazem pogłębia jego wszechstronne zrozumienie. Koncepcja ta, ewentualnie realizowana z pomocą Internetu i mediów, może ponadto istotnie ułatwić m. in. uczenie się „przez wgląd i zrozumienie” oraz

25 Np. E. Turkowska, Über die Notwendigkeit des handlungsorientierten Umgangs mit Literatur im Hochschulbereich, [w:] A. Mrożewska (red.), Philologische OstseeStudien, Koszalin 2009, s. 113-121. Por. też jej monografię: E. Turkowska, Literatur auf der Datenautobahn. Zur Rolle der digitalen Literatur im Kommunikations- und Medienzeitalter, Baltmannsweiler 2016 i jej przywoływaną we wcześniejszym przypisie pracę: E. Turkowska, Integracyjny model kształcenia..., op. cit. Autorka wpisuje tę ideę dydaktyczną (handlungsorientierter Literaturunterricht) w myśl literaturoznawstwa poststrukturalistycznego oraz teorii dekonstrukcjonizmu i estetyki recepcji, podważających zasadność szukania jednoznacznych interpretacji czy immanentnego sensu dzieła. Celem użycia tej metody nie jest jednak praktyczne wspieranie określonej wizji literaturoznawczej, ale realizacja zamierzonych celów dydaktycznych. 
„przez rozwiązywanie problemów”, co istotnie sprzyja osiąganiu naszych celów dydaktycznych.

Taka metoda (która zresztą bodaj najbardziej przydaje się w zaawansowanych/końcowych fazach pracy nad danym tekstem) nie powinna wszak zbyt dyskryminować innych, także ze względu na kompleksową realizację celów. Np. więc tradycyjny wykład, wspierany technikami audiowizualnymi, byłby nie mniej pożądany i nieodzowny niż aktywizacja słuchaczy czy rozważania teoretyczne (konieczne choćby w odpowiedziach na powyższe pytania opcji literaturoznawczych). Inną fantastyczną propozycję metodyczną, znakomicie strukturyzującą zajęcia, stanowi tzw. flipped classroom („odwrócona sala lekcyjna"), polegający na teoretycznym przygotowaniu się studenta przed zajęciami - na podstawie wszakże materiałów przygotowanych przez prowadzącego - i następującym praktycznym wykorzystaniu nabytej wiedzy na ćwiczeniach czy konwersatoriach ${ }^{26}$. Metoda ta wspaniale harmonizuje i uzupełnia się np. z handlungsorientierter Unterricht, istotnie rozwija zakres kolaboracji studentów z prowadzącym przy przygotowaniu zajęć oraz pogłębia ich interakcje z materiałem, co wydaje się szczególnie efektywne względem nauki lepszego rozumienia literatury ${ }^{27}$.

Wspomogą ją ponadto egzemplifikacje, w praktyce zadziwiająco często a niezrozumiale zaniedbywane. W każdym jednak możliwym przypadku, empiria powinna po prostu zostać ilustracyjnie związana z teorią. Jeśli więc student usłyszy o powieściach mash-up, graficznych czy „maksymalistycznych”28, to powinien je choćby pobieżnie przej-

${ }^{26}$ Podstawowe informacje o technice flipped classroom można przeczytać np. na anglojęzycznej Wikipedii: https://en.wikipedia.org/wiki/Flipped_classroom [dostęp: 10.10.2017].

27 Zarazem flipped classroom wymaga rozważnego stosowania celem uniknięcia pewnych pułapek, o których można wywnioskować z artykułu zalinkowanego w poprzednim przypisie.

${ }^{28}$ Grupa wyróżniona przez S. Ercolino w The Maximalist Novel: From Thomas Pynchon's Gravity's Rainbow to Roberto Bolano's 2666, Londyn 2014. Zaliczają się do niej zazwyczaj olbrzymie objętościowo, multitematyczne i różnorako hybrydowe powie- 
Szymon Gębuś - W kierunku pełni. O literaturze światowej...

rzeć i ewentualnie podyskutować o nich; powinien zajrzeć na stronę internetową wordswithoutborders.org, propagującą twórczość młodych autorów z różnych krajów a także „naocznie” zaznajomić się z wydawnictwami poświęconymi literaturze zagranicznej/światowej29, itd. To drobiazg, godny wszak przypomnienia, bo mogący radykalnie wzbogacić doświadczenie studenta.

0 ile jednak pewnym narzędziom dydaktycznym można wróżyć większą od innych przydatność, to nie można ich w żadnym wypadku absolutyzować; przeciwnie, mimo wszystko wypada przyznać, że w tym przypadku cel uświęca dowolne środki i że bodaj każda metoda spełni zadanie, o ile skutecznie poprowadzi do celu ${ }^{30}$. Niemałe znaczenie posiada wszakże fakt, że właściwe podejście dydaktyczne demonstruje studentom wzorce prawidłowych, efektywnych modeli nauczania, co może wspomagająco wpłynąć na ich samodzielną pracę zawodową 31 .

ści jak np. Tęcza grawitacji Thomasa Pynchona (Warszawa 2006), Infinite Jest Davida Fostera Wallace'a (Nowy Jork 1996) czy 2666 Roberta Bolaño (Warszawa 2012).

${ }^{29}$ Studenci mogą też poćwiczyć rolę redaktora/zespołu redakcyjnego polskojęzycznego miesięcznika czy kwartalnika poświęconego literaturze światowej, zaproponować jego tytuł, szatę graficzną oraz szkicowo przedstawić treść jednego numeru.

30 Wypada też jednak pozbyć się niechęci wobec metod aktywizujących studentów, chyba ciągle tkwiącej w niektórych polskich nauczycielach akademickich. I zapoznać się z książką D. Damroscha (red.), Teaching World Literature, Nowy Jork 2008, by przekonać się, że m. in. takich metod używa się także na znakomitych uczelniach amerykańskich.

31 „Die Gewöhnung an das moderne handlungsorientierte Methodenrepertoire hilft, die verhängnisvolle Dominanz des Frontalunterrichts bei werdenden Lehrern zu verdrängen und sie zu zeitgemäßen, modernen Didaktikern zu erziehen. Unsere Studierenden kommen immer noch aus Schulen, in denen trotz (oder gerade wegen) einer permanenten Schulreform Handlungsorientierung im Unterricht entweder überhaupt nicht vorkommt oder zu raren Feiertagsbeschäftigungen gehört. Innerhalb von drei Jahren, die zur Lizenziat-Prüfung führen, müssen sie in der didaktischen Hinsicht umerzogen werden, die alten didaktischen Vorbilder kritisch reflektieren und sich neue Lehrgewohnheiten aneignen. Das ist ein lange andauernder Prozess, zur Vollendung dessen der Methodiklehrgang allein nicht ausreichen kann. Notwendig ist seine Unterstützung und Ergänzung in allen anderen Lehrgängen (nicht nur in der Sprachpraxis, sondern auch in Geschichte, Landeskunde, Kulturkunde, u.s.w.), in denen dank der handlungsorientierten Unterrichtsgestaltung die künftigen Lehrer Funktionieren und Wirkung der Handlung im Unterricht praxisnah erfahren und erleben können". E. Turkowska, Über die Notwendigkeit.., op. cit., s. 119. Zaś pomija- 


\section{Z czego korzystać?}

Z wszystkiego co pomoże głębiej i wszechstronniej zrozumieć literaturę - i sprawdzi się w uniwersyteckim trybie zajęć. Wśród multum potencjalnie przydatnych materiałów znajdą się tedy także wysokospecjalistyczne biografie, szczegółowe eseje, monografie etc., pożytkowane wprawdzie głównie przez profesjonalnych badaczy literatury, jednak mogące znaleźć zastosowanie (respektując ich poziom trudności dla studentów, jak i konkretną przydatność dydaktyczną) także na naszym kursie. Nieogarniona liczba takich prac udaremnia zamysł ich choćby pobieżnego omówienia, nawet po jej ewentualnym okrojeniu względem jednej, wybranej ramy tematycznej. Wyłącznie więc dla pewnego oględnego przykładu - jeśli prowadzący zechce zaznajomić studentów z fascynującymi acz dość skomplikowanymi zagadnieniami przestrzeni w literaturze (światowej), to będzie mógł wybierać m. in. z pism Gottholda Ephraima Lessinga, Isaaca Newtona, Kartezjusza, Wilhelma Dilthey'a, Romana Ingardena, Immanuela Kanta, Emila Durkheima, Henryka Markiewicza, Janusza Sławińskiego, Michała Bachtina czy Jurija Łotmana ${ }^{32}$, prócz mnóstwa innych przyczynków, z rodzimymi publikacjami w zakresie tzw. geopoetyki (Anna Kronenberg, Elżbieta Rybicka) na czele 33 .

Ze swojej strony chciałbym natomiast przedstawić prace o, ogólnie biorąc, bardziej „przeglądowym” charakterze, zazwyczaj więc dość pojemne przedmiotowo (fakt, że niekiedy kosztem przenikliwości), za to potencjalnie przydatne $\mathrm{w}$ różnych ramach tematycznych. Teksty te można zarazem różnorako pożytkować; tak jak w przypadku wzmian-

jąc nauczycielstwo - praca np. w korporacji polega niejednokrotnie na sporządzaniu prezentacji czy przygotowywaniu szkoleń, itp. Być może pouczające zajęcia uniwersyteckie pomogłyby też przyszłym absolwentom filologii w lepszym radzeniu sobie $\mathrm{z}$ takimi zadaniami, podczas pracy $\mathrm{w}$ firmach komercyjnych.

32 Oczywiście, prowadzący powinien znać odnośne prace i zagadnienia na poziomie pozwalającym na przystępne i kompetentne wyjaśnienie ich studentom.

${ }^{33}$ A. Kronenberg, Geopoetyka. Zwiqzzki literatury i środowiska, Łódź 2015; E. Rybicka, Geopoetyka. Przestrzeń i miejsce we współczesnych teoriach i praktykach literackich, Kraków 2014, z dalszą bibliografią przedmiotową. 
Szymon Gębuś - W kierunku pełni. O literaturze światowej...

kowanych prac specjalistycznych, polecając je do lektury lub przygotowując zajęcia na ich bazie oraz wykorzystując je częściowo lub w całości, o czym w każdym przypadku decydowałby prowadzący.

Wybrane teksty podzieliłem doraźnie na kilka grup, celem klarowności ignorując pewne zbieżności w poszczególnych z nich, zarazem ze świadomością niemożności uniknięcia niejakich niekonsekwencji w podziale.

\subsection{Pisarze o (nie tylko) pisarzach}

Sięgnięcie do „pomocy naukowych” spod pióra pisarzy może na pierwszy rzut oka przynieść co najmniej dwa dobrodziejstwa. Wykorzystując je, poznajemy bowiem ich twórczość jakby od razu „dubeltowo"; Kundera piszący o Tołstoju wzbogaca wszak znajomość obojga, itd. Drugi istotny atut to, wcale często spotykana, pewna myślowa świeżość i stylistyczna uroda pisarskich wywodów. Niejednokroć bowiem twórcy literatury potrafią ją naświetlać oryginalnie, frapująco, kreując zadziwiające nieraz spostrzeżenia w sformułowaniach „kontestujących” retorykę literaturoznawczą czy krytycznoliteracką. Weźmy wspomnianego Kunderę i jego inspirujący zbiorek Sztuka powieści $^{34}$. Pokrótce analizując gatunek Czech ujmuje myśli m. in. w takich „neologizmach”, jak „mądrość niepewności”, „świat życia codziennego”, „oświetlenie postaci” czy „artykulacja powieści”, które studenci mogą na konwersatorium np. spróbować zdefiniować według myśli autorskiej bądź alternatywnie ${ }^{35}$. Intelektualną wirtuozerią i pomysłowością imponuje Kundera także w podobnie godnych polecenia Zasłonie $^{36}$ i Zdradzonych testamentach ${ }^{37}$.

${ }^{34}$ M. Kundera, Sztuka powieści. Eseje, Warszawa 1998.

35 Do głębszego zrozumienia rozważań Kundery z tego zbioru, zwłaszcza z jego pierwszego rozdziału, konieczne byłoby jednak wcześniejsze przyswojenie sobie następującego wykładu: E. Husserl, Kryzys europejskiego człowieczeństwa a filozofia, Warszawa 1993, bazy rozważań czeskiego pisarza.

36 M. Kundera, Zasłona. Esej w siedmiu częściach, Warszawa 2006.

37 M. Kundera, Zdradzone testamenty, Warszawa 2015. 
Wyróżniłbym także błyskotliwe popisy Orhana Pamuka w Pisarzu naiwnym i sentymentalnym ${ }^{38}$, w jakimś stopniu autokomentujące jego twórczość, ale też z mnóstwem intrygujących odwołań do Flauberta, Tołstoja, Faulknera czy Balzaca jak też koniecznością przypomnienia Schillerowskiego rozróżnienia. Trochę abstrahując - można żałować, że polscy germaniści (z dość niejasnych powodów) tak skąpo (bojaźliwie? bez przekonania o takiej potrzebie? o ewentualnych korzyściach?) korzystają - jeśli w ogóle - z pozaniemieckich źródeł „sekundarnych” przy omawianiu literatur niemieckojęzycznych. Tymczasem np. uwagi Vladimira Nabokova z jego Wykładów o literaturze ${ }^{39}$ o Przemianie Franza Kafki można zalecić do obowiązkowego (!) wykorzystywania na ćwiczeniach z tej lektury, co słuchaczom mogłoby przynieść olbrzymią korzyść intelektualną. Doliczamy je zatem do naszych sugestii; inne mini perełki to $A B C$ czytania Ezry Pounda ${ }^{40}$, lekkostrawna Opowieść się rozpoczyna Amosa Oza ${ }^{41}$ oraz eseje Mario Vargasa Llosy Prawda kłamstw ${ }^{42}$, o 25 powieściach XX wieku, pióra m. in. Dos Passosa, Joyce'a, Orwella, Nabokova czy Hemingwaya, godne polecenia także na zajęcia z literatury niemieckojęzycznej ${ }^{43}$ aczkolwiek można ubolewać, że nie przełożono dotąd na polski rozszerzonej wersji tej pozycji ${ }^{44}$. Z innych wydawnictw hiszpańskojęzycznych przydać się

\footnotetext{
38 0. Pamuk, Pisarz naiwny i sentymentalny. Wykłady harwardzkie, 2009, Kraków 2012.

${ }^{39}$ V. Nabokov, Wykłady o literaturze, Warszawa 2016. Warte uwagi są tu m. in. rozdziały o Ulissesie, Pani Bovary czy o dziele Prousta.

40 E. Pound, $A B C$ czytania, „Teksty: teoria literatury, krytyka, interpretacja” 1981, nr 3 (57), s. 161-179.

${ }^{41}$ A. Oz, Opowieść się rozpoczyna, Warszawa [bdw; pierwsze wydanie 1996].

42 M. V. Llosa, Prawda kłamstw. Eseje o literaturze, Poznań 1999.

43 Znaleźć tu można bowiem szkice o utworach Manna, Hessego, Canettiego, Frischa, Grassa i Bölla.

${ }^{44}$ Jej pierwodruk w języku hiszpańskim pod tytułem La verdad de las mentiras (1990) stanowił podstawę podanej w bibliografii polskiej edycji z 1999 roku. W roku 2012, pod niezmienionym tytułem, Llosa opublikował rozszerzoną (o omówienia 10 utworów i końcowy esej La literatura y la vida) wersję zbioru, ta jednak nie doczekała się dotychczas polskiej translacji. W październiku 2017 roku wydano wszak kolejną niebeletrystyczną pozycję Llosy o wyrazistym tytule $O$ czytaniu i pisaniu. Wybór eseistyki, Gdańsk 2017.
} 
Szymon Gębuś - W kierunku pełni. O literaturze światowej...

może Cómo dibujar una novela Meksykanina Martína Solaresa z niecodzienną propozycją parcelacji powieści ${ }^{45}$. Z kolei Wierność przegranej Becketta ${ }^{46}$ warto wykorzystać choćby dla jego eleganckich rozważań o Prouście. Wreszcie wśród krajowych autorów inteligentnie i przenikliwie dywagował o literaturze np. Stanisław Lem; można podyskutować z jego tezami o recepcji z Filozofii przypadku47 (rozdział Los społeczny, czyli znaczenia dzieła) czy o „nowej powieści” (podrozdziały Nowa powieść i nowa fizyka oraz Nowa powieść i matematyka).

Część pozycji można wszak uznać za przypuszczalnie mniej tutaj przydatne; np. Pisarza i jego zmory Ernesta Sábato48, Dziwniejsze brzegi Johna Maxwella Coetzee'ego ${ }^{49}$, I ślepy by dostrzegł George Orwella50, Ojczyzny wyobrażone Salmana Rushdiego ${ }^{51}$ oraz nieco powierzchowne eseje Carlosa Fuentesa ze zbioru $W$ to wierzę ${ }^{52}$. W 2016 roku opublikowano u nas $O$ literaturze Julio Cortázara, gdzie rozprawia on jednak głównie o własnym pisarstwie ${ }^{53}$. Z kolei Wykłady amerykańskie Italo Calvino ${ }^{54}$ czy Szkice literackie Thomasa Stearnsa Eliota$^{55}$ to prace tyleż arcyciekawe co troszkę bardziej wymagające, w czym nieco zbliżają się do esejów Kundery; przystępne zatem dla

\footnotetext{
45 Na powieści m. in. „rekiny, „wieloryby” czy „ośmiornice”; M. Solares, Cómo dibujar una novela, Meksyk 2014. Pisarz osobiście zaprezentował tą typologię w Polsce, rok po wydaniu książki, odwiedzając nasz kraj z okazji XII Międzynarodowego Festiwalu Kryminału we Wrocławiu.

${ }^{46}$ S. Beckett, Wierność przegranej, Kraków 1999; warto tu też zajrzeć do posłownych wyjaśnień Antoniego Libery.

47 S. Lem, Filozofia przypadku, Kraków 1960.

48 E. Sábato, Pisarz i jego zmory, Kraków 1987.

49 J. M. Coetzee, Dziwniejsze brzegi. Eseje literackie 1986-1999, Kraków 2008. Przydatniejsza wydaje się ich kontynuacja: J. M. Coetzee, Wewnętrzne mechanizmy. Eseje literackie 2000-2005, Kraków 2012.

50 G. Orwell, I ślepy by dostrzegł. Wybór esejów i felietonów, Kraków 1990.

${ }^{51}$ S. Rushdie, Ojczyzny wyobrażone, Poznań 2013.

52 C. Fuentes, $W$ to wierzę, Warszawa 2003. Oprócz szeregu „nieliterackich” tematów, Meksykanin dywaguje też o Kafce, Balzacu, Faulknerze, Szekspirze i o powieści w ogóle.

${ }^{3}$ Choć znajdzie się co nieco także np. o Kafce; J. Cortázar, O literaturze. Wykłady w Berkeley, 1980, Gdańsk 2016.

${ }^{54}$ I. Calvino, Wykłady amerykańskie. Sześć przypomnień dla przyszłego tysiąclecia, Warszawa 2009.

55 T. S. Eliot, Szkice literackie, Warszawa 1963.
} 
studentów dość dobrze już oczytanych w literaturze światowej i zainteresowanych w jej samodzielnych eksploracjach.

\subsection{Przez literaturę na przestwór}

Do tej grupy zaliczają się pozycje autorów najróżniejszego autoramentu, wewnętrznie scalone przekrojowymi ujęciami tematów i „przeglądowym” traktowaniem elementów procesu historycznoliterackiego. Wybrałem z nich jedynie nieliczne przykłady, które uważam jednakże za intrygujące poznawczo i cenne dydaktycznie. Jak np. poniższe dwie prace:

1. Thomas C. Foster, How to Read Literature Like a Professor ${ }^{56}$ oraz

2. David Damrosch, How to Read World Literature ${ }^{57}$.

Zwodniczo „poradnikowe” tytuły ukrywają supererudycyjne wywody, z których warto skorzystać w całości lub fragmentarycznie. W ten sam sposób - wybiórczo - można też potraktować tematycznie zbliżone do siebie pozycje: The Seven Basic Plots Christophera Booke$\mathrm{ra}^{58}$, Story Structure Architect Victorii Lynn Schmidt ${ }^{59}$ oraz Twenty Master Plots and How to Build Them Ronalda B. Tobiasa ${ }^{60}$. Najoględniej biorąc, traktują one o kategoryzacji narracji w oparciu o jej fabułę/temat i konstrukcję. Np. Christopher Booker wyselekcjonował 7 archetypicznych schematów narracyjnych 61 , Tobias - 20, Lynn Schmidt aż 55. Student zaś mógłby np. przyporządkowywać badane teksty do tych kategorii, według jednej bądź jednocześnie wszystkich trzech propozycji.

56 T. C. Foster, How to Read Literature Like a Professor. A Lively and Entertaining Guide to Reading Between the Lines, Nowy Jork 2003.

57 D. Damrosch, How to Read World Literature, Chichester 2009.

58 C. Booker, The Seven Basic Plots: Why We Tell Stories, Londyn 2004.

59 V. Lynn, Story Structure Architect. A Writer's Guide to Building Dramatic Situations \& Compelling Characters, Cincinatti 2005.

60 R. B. Tobias, Twenty Master Plots and How to Build Them, Londyn 1995.

61 Oryginalnie nazwanych: The Meta-Plot, Overcoming the Monster, Rags to Riches, The Quest, Voyage and Return, Comedy, Tragedy, Rebirth. 
Szymon Gębuś - W kierunku pełni. O literaturze światowej...

Z nowszych pozycji niemieckojęzycznych trzeba odnotować dwie ważne prace, mianowicie Die neue Weltliteratur und ihre großen Erzähler autorstwa Siegfried Löffler62 oraz Meilensteine der Weltliteratur pod redakcją Dietera Lampinga63, ze starszych - Was ist gute Literatur? Hansa-Dietera Gelferta64. Z dorobku Umberto Eco można (także wybiórczo) poczytać 0 literaturze 65 i Szaleństwo katalogowania66. Rozszerzenie o przekrojową eseistykę pozwoliłoby zaś włączyć np. opracowanie Raymonda Federmana o powieściach eksperymentalnych67, klasyczny esej Wolfganga Kaysera Powstanie i kryzys powieści nowoczesnej68 oraz tekst Ericha Kahlera Przeobrażenie nowoczesnej powieści69. Student mógłby np. opracować typologię postaci jakiegoś utworu w oparciu o propozycje tego ostatniego (postacie „symboliczne”, „syntetyczne” i „paraboliczne”).

Do odrębnego konglomeratu zaliczam pozycje o dystynktywnych cechach „popularnoliterackich”, nacelowane raczej na szerszą i być może trochę mniej wymagającą publiczność czytelniczą. Np. Moją historię czytania Alberto Manguela70, którą szanujący się prowadzący znać po prostu musi, dla bogactwa jej wiedzy, bardzo atrakcyjnie podanej; następnie, Księge ksiąg utraconych Stuarta Kelly'ego ${ }^{71}$ oraz Pisarzy jednej książki Olgi Romańskiej-Maliny72. Rozszerzyć tę grupę

\footnotetext{
62 S. Löffler, Die neue Weltliteratur und ihre großen Erzähler, Monachium 2013.

63 D. Lamping (red.), Meilensteine der Weltliteratur. Von der Aufklärung bis in die Gegenwart, Stuttgart 2015.

${ }^{64}$ H.-D. Gelfert, Was ist gute Literatur? Wie man gute Bücher von schlechten unterscheidet, Monachium 2010.

65 U. Eco, O literaturze, Warszawa 2003.

66 U. Eco, Szaleństwo katalogowania, Poznań 2009.

${ }^{67}$ R. Federman, Czym sq powieści eksperymentalne i dlaczego ich się nie czyta?, „Literatura na Świecie” 1984, nr 9, s. 215-224.

68 W. Kayser, Powstanie i kryzys powieści nowoczesnej, „Przegląd Humanistyczny” 1960, nr 1, s. 61-89.

${ }^{69}$ E. Kahler, Przeobrażenia nowoczesnej powieści, „Pamiętnik Literacki” 1970, nr 3, s. 231-239.

${ }^{70}$ A. Manguel, Moja historia czytania, Warszawa 2003.

${ }^{71}$ S. Kelly, Księga ksiag utraconych, Warszawa 2008.

72 O. Romańska-Malina, Pisarze jednej książki, Warszawa 2011; to część ciekawej serii Literatura i kontrowersje.
} 
powinna też najnowsza praca Davida Damroscha Around the World in $80 \mathrm{Books}^{73}$.

Jeszcze inną tworzą szkice krytycznoliterackie. Z polskich, Berezowska Proza $z$ importu ${ }^{74}$, prócz demonstracji oryginalnych perspektyw interpretacyjnych, powinna posłużyć za wzorzec krótkich esejów i recenzji. Czytając Józefa Czapskiego ${ }^{75}$ warto z kolei wykorzystać choćby dla jednego rozdziału - Proust w Griazowcu, zaś w ostatnich latach bodaj najrezolutniej bawił się u nas piórem krytyk i tłumacz Jan Gondowicz ${ }^{76}$, aczkolwiek tylko mimochodem nawiązując do literatury światowej.

W USA pięknie o literaturze pisze Michael Dirda, znakomity od lat kolumnista „Washington Post”, laureat Nagrody Pulitzera. Dirdę czyta się $\mathrm{z}$ wielkim szacunkiem i podziwem - bo mało kto wypowiada się jak on, z autentyczną pasją i namiętnością. I dysponując tak fenomenalnym oczytaniem; lektura jego Classics for Pleasure, nawet u osoby $\mathrm{w}$ miarę solidnie zaznajomionej $\mathrm{z}$ dobrymi książkami, zapewne pozostawi wrażenie typu ,jak wielu doskonałych rzeczy w ogóle nie znam". To zbiór esejów o utworach beletrystyki i filozofii, wartościowych, choć spoza powszechnie znanego „paradygmatu” kanonicznych dzieł. Amerykanin, posiadacz doktoratu z komparatystyki „bluszczowego" uniwersytetu Cornell w Nowym Jorku, występuje w nich jednak bardziej jako piewca i obsesjonat literatury niż krytyk literacki czy naukowiec ${ }^{77}$. Bezkresną wiedzą o pisarstwie, wykładaną w porywającym stylu, imponuje też w Readings. Essays and Literary Enterteinments ${ }^{78}$, wyborze esejów z „Washington Post” z lat 1992-1999. Tomie, który powinien zachwycić każdego, kto choć w części ubóstwia książki, tak jak amerykański ekspert; rozdziały jak Commencement Advice

73 Zapowiedziana na listopad 2017 roku.

${ }^{74} \mathrm{H}$. Bereza, Proza z importu. Szkice literackie, Warszawa 1979.

75 J. Czapski, Czytając, Kraków 2015.

76 Zwłaszcza w: J. Gondowicz, Duch opowieści, Warszawa 2014.

77 Anonsując: „In general, my approach is that of a passionate reader, rather than that of a critic or scholar." M. Dirda, Classics for Pleasure, Orlando 2007, s. 2.

78 M. Dirda, Readings. Essays and Literary Enterteinments, Bloomington 2000. 
Szymon Gębuś - W kierunku pełni. O literaturze światowej...

czy Mememormee są słowem wspaniałe. Dirda pisze w osobnej lidze, a literaturę poznał do najdalszych granic.

Brytyjka Ann Morgan postanowiła z kolei przeczytać po książce z każdego kraju świata; pokłosie jej przedsięwzięcia ukazało się w 2015 roku w pracy The World Between Two Covers ${ }^{79}$. Nie jest to jednak np. zbiór komentarzy do przestudiowanych w sumie 197 pozycji; to opowieść, w której na tle lektur pisarka eseistycznie mierzy się z ogólnoświatowymi zagadnieniami literatury: kwestiami kulturowego dziedzictwa, cenzury, propagandy, narodowej tożsamości czy tłumaczeń. Całkiem osobno wyróżniłbym ponadto pracę Andrewa Bennetta i Nicholasa Royle'a An Introduction to Literature, Criticism and Theory ${ }^{80}$, trudną do sklasyfikowania a oferującą szeroki przegląd różnorodnych kategorii analitycznych (morfologicznych, estetycznych, tematycznych etc.), jak: narracja, historia, tragedia, śmiech, przyjemność, suspens, postmodernizm, Bóg, ideologia, z praktycznymi przykładami i bibliografią. To bodaj jedna z najlepszych pozycji do wykorzystania, także w roli samodzielnej lektury dla studentów. Do miana najbardziej ekscytującej książki 2017 roku o literaturze światowej pretenduje zaś The Written World. The Power of Stories to Shape People, History, Civilization Martina Puchnera81. Amerykański badacz pomysłowo strukturyzuje wywody w oparciu o cztery wyznaczone przez siebie etapy rozwoju literatury (działalność skrybów składających konstytutywne teksty, np. Biblię hebrajską - „literatura nauczycielska” czyli spisane wypowiedzi charyzmatycznych postaci jak Jezus czy Budda - pojawienie się samodzielnych twórców jak Cervantes epoka masowej produkcji i konsumpcji literackiej), szerzej też ujmuje teksty egzotyczne dla np. europejskich czytelników, jak malijską legendę o Sundiacie czy świętą księgę majańską Popol Vuh. Wreszcie,

${ }^{79}$ A. Morgan, The World Between Two Covers, Nowy Jork 2015; pod takim tytułem, praca ta ukazała się na rynkach USA i Kanady. W Wielkiej Brytanii zaś jako Reading the World. Confessions of a Literary Explorer.

${ }^{80} \mathrm{~A}$. Bennett, N. Royle, An Introduction to Literature, Criticism and Theory. Third Edition, Harlow 2004.

81 M. Puchner, The Written World. The Power of Stories to Shape People, History, Civilization, Nowy Jork 2017. 
w dyskusjach o kanonie światowym nie może zabraknąć Harolda Blooma i jego The Western Canon $^{82}$, choć na dobrą sprawę, można w niej wykorzystać wyłącznie wstęp - An Elegy for the Canon.

$\mathrm{W}$ jeszcze odrębnym podzbiorze umieszczam pozycje typu „o literaturze łatwo i przyjemnie”, o potocznej retoryce i publicystycznych uproszczeniach. Nawet trudno je merytorycznie wartościować, tutaj liczy się bowiem możliwość wyłuskania atrakcyjnych i chwytliwych ciekawostek, błahostek, aluzji, znalezienia jakichkolwiek inspiracji. Literatura od kuchni ${ }^{83}$ (o literaturze i jedzeniu) przyda się tu tak samo jak Literacki almanach alkoholowy (o literaturze i piciu) ${ }^{84}$ i wszystko co „lekkie” a dostatecznie treściwe i zajmujące. Czyli np. także Czytadła Agnieszki Osieckiej85, ze skąpymi wprawdzie naświetleniami zagranicznych dzieł. W zbliżonej poetyce pisała o „lekturach nadobowiązkowych" Wisława Szymborska ${ }^{86}$, w krótkich błyskotkach dla miłośników książkowych rozmaitości. Można tu także wliczyć tomik Ex libris Amerykanki Anne Fadiman ${ }^{87}$, ewentualnie Zamieszkać $w$ Bibliotece Jana Tomkowskiego ${ }^{88}$ czy nawet antyczne 500 zagadek literackich z 1960 roku$^{89}$.

${ }^{82}$ H. Bloom, The Western Canon. The Books and School of the Ages, Nowy Jork San Diego - Londyn 1994.

83 B. Deptuła, Literatura od kuchni, Warszawa 2013.

${ }^{84}$ A. Przybylski, Literacki almanach alkoholowy, Gdańsk 2016.

85 A. Osiecka, Czytadła. Gawędy o lekturach, Warszawa 2010.

86 Najpełniej wydane jako: W. Szymborska, Wszystkie lektury nadobowiązkowe, Kraków 2015.

${ }^{87}$ A. Fadiman, Ex libris. Wyznania czytelnika, Warszawa 2004. Na polski nie została przełożona jej inna książka pt. Rereadings, Nowy Jork 2005, cenna jako lektura uzupełniająca dla prowadzącego.

88 J. Tomkowski, Zamieszkać w Bibliotece, Ossa 22008. Wyselekcjonowane, w rozdziale Ciagle układamy kanon, znakomitości XX wieku mogą posłużyć dodatkową sugestią przy układaniu listy lektur.

${ }^{89}$ A. Wasilewski, 500 zagadek literackich, Warszawa 1960. 
Szymon Gębuś - W kierunku pełni. O literaturze światowej...

\subsection{Podręczniki}

Kolejną grupę wyróżnia zmiennie nasilone zdydaktyzowanie treści ${ }^{90}$, to zatem opracowania o mniej lub bardziej eksplicytnym charakterze podręcznikowym. Godne rekomendacji rozbudowane kompendium anglojęzyczne to Beginning Theory Petera Barry'ego ${ }^{91}$, nieco nierówne w poszczególnych rozdziałach, niewystarczające też do pożądanego poziomu zrozumienia teorii literaturoznawczych, za to z interesującymi ćwiczeniami i, we fragmentach, bardzo pomocne. Świetnie wypada też Studying Fiction Roya Johnsona92, oparte na przykładowych lekturach (close reading) krótkiej prozy Conana Doyle’a, Dickensa czy Conrada. Zupełnie nie przeszkadza, że nie zawsze została ona przełożona na polski, bo liczą się tutaj przede wszystkim wskazówki odnośnie rozumiejącego czytania i analizowania, przydatne także przy rozleglejszych wypowiedziach literackich. Z zasobów niemieckojęzycznych wciąż warte uwagi wydaje się Wie interpretiert man einen Roman Hansa-Dietera Gelferta ${ }^{93}$, z jego analizami (cudzego niekiedy autorstwa) interesujących i wzbogacających postrzeganie rozróżnień, np. na postaci „płaskie” i „okrągłe” czy na narrację „sceniczną” i „panoramiczną”94 oraz ze szkieletowymi interpretacjami kilku arcydzieł, jak Wielkie nadzieje czy Ulisses. Wreszcie, z polskiego dorobku, wyróżniają się prace Jana Tomkowskiego: Dzieje literatury powszechnej ${ }^{95}$, systematyczne, przejrzyste, cenne dla podstawowego uporządkowania faktów i raczej do doraźnego wykorzystywania oraz (przy pewnym rozszerzeniu rozumienia „formuły podręcznikowej") Literatura powszechna według Jana Tomkowskiego ${ }^{96}$ -

90 Przedstawianie jej w dydaktycznie uproszczonej, „podręcznikowej” retoryce, wzbogacone niekiedy ćwiczeniami itp.

91 P. Barry, Beginning Theory. An Introduction to Literary and Cultural Theory, Manchester 1995, kilkakrotnie wznawiana.

92 R. Johnson, Studying Fiction, Manchester-Nowy Jork 1994.

93 H.-D. Gelfert, Wie interpretiert man einen Roman, Stuttgart 2006.

$94 \mathrm{~Np}$. to rozróżnienie pochodzi z pracy P. Lubbocka The Craft of Fiction, Londyn 1921.

95 J. Tomkowski, Dzieje literatury powszechnej, Warszawa 2008.

96 Idem, Literatura powszechna według Jana Tomkowskiego, Warszawa 1997. 
oszałamiająca wizualnie, z inspirującymi kontekstami, z przyjętej koncepcji mocno jednak skrótowa. Dydaktyczne walory cechują też przejrzyście ułożony skrypt Tomasza Małyszka Literatura niemiecka $w$ teorii i praktyce ${ }^{97}$ z pouczającymi rozdziałami Interpretowanie czy Pierwsza recepcja. Wreszcie, w osobnej podgrupie widziałbym sztandarowe, rodzime wydawnictwa o (rozumianym tu dość metaforycznie) charakterze „encyklopedycznym”: Historia literatury światowej $w$ dziesięciu tomach ${ }^{98}$, Dzieje literatur europejskich pod redakcją Władysława Floryana ${ }^{99}$ oraz Teorie literatury XX wieku Anny Burzyńskiej i Michała Pawła Markowskiego ${ }^{100}$, pamiętając ponadto o licznych a niemożliwych tu do wyliczenia tomach przeglądowych historii literatur poszczególnych krajów czy regionów, słownikach, leksykonach czy antologiach literatury światowej ${ }^{101 .}$

\subsection{Syntezy}

W osobnej mini grupie da się wyszczególnić dwie anglojęzyczne „maxisyntezy”, skrótowe omówienia rozległej liczby tekstów: Masterpieces of World Literature Franka N. Magilla z 1989 roku102, z kilkuset wszelkiej maści utworami scharakteryzowanymi na lepiej niż 950 stronach, tworzącymi zarazem swego rodzaju zgrabny poradnik w kwestii „na co zwrócić uwagę studentów”? Druga propozycja to Sparknotes 101. Literature ${ }^{103}$.

97 T. Małyszek, Literatura niemiecka w teorii i praktyce, Wrocław 2007.

98 T. Skoczek (red.), Historia literatury światowej $w$ dziesięciu tomach, Bochnia Kraków - Warszawa 2003-2006.

${ }^{99}$ W. Floryan (red.), Dzieje literatur europejskich, tomy I-III, Warszawa 19771991.

100 A. Burzyńska, M. P. Markowski, Teorie literatury XX wieku. Podręcznik, Kraków 2006.

101 Warto choćby przejrzeć dwie najbardziej renomowane, wielotomowe antologie: The Longman Anthology of World Literature oraz The Norton Anthology of World Literature, redagowane przez m. in. Davida Damroscha i Martina Puchnera.

102 F. N. Magill (red.), Masterpieces of World Literature, Nowy Jork 1989.

103 Sparknotes 101. Literature, Nowy Jork 2004 (opracowanie zbiorowe). Publikacja nawiązuje do strony internetowej sparknotes.com. 
Szymon Gębuś - W kierunku pełni. O literaturze światowej...

\subsection{Humanistyka}

Idealnie, gdyby prowadzący potrafił wkomponowywać w zajęcia wiedzę zaczerpniętą z wartościowych nowości humanistyki. Takich jak np. jedna z najgłośniejszych książek humanistycznych ostatnich lat pt. Zmierzch przemocy (2011), w której harwardzki profesor Steven Pinker ${ }^{104}$ analizuje (w jednym z podrozdziałów czwartej części) relacje między eskalacją czytelnictwa i dostępu do książek a natężeniem przemocy. Prowadzący powinien tedy zaznajomić się też $\mathrm{z}$ pozycją Petera Singera The Expanding Circle ${ }^{105}$ - którą istotnie w odnośnym fragmencie podpiera się Pinker - by uzyskane informacje twórczo zintegrować z treścią kursu, który sporo może skorzystać na ubogacającym wykorzystaniu „postronnych” publikacji.

Niezależnie jednak od celowej metodyki i zaaplikowanych „suplementów”, opierałby się on na pewnej konstelacji tekstów beletrystycznych. Stąd ostatnie pytanie:

\section{Jakie lektury?}

Takie, które nauczą studentów lepiej zrozumieć literaturę i pełniej jej doświadczać. Dostatecznie też trwale rozszerzą ich „wewnętrzną bibliotekę" (Pierre Bayard)106, urzekną atrakcyjną a mądrą treścią, posłużą jako brama do wniknięcia w historyczno-społeczne realia oraz wymiary intertekstualne, spełniając przy tym wymóg przyzwoitego poziomu artystycznego. Standardy wyboru tekstu określałaby zatem nie (tyle) jego przynależność do „klasyki”107, lecz - przy poszanowaniu (choćby intuicyjnie rozumianej) rangi artystycznej - jego

104 S. Pinker, Zmierzch przemocy. Lepsza strona naszej natury, Poznań 2015.

105 P. Singer, The Expanding Circle. Ethics, Evolution, and Moral Progress, Princeton - Oxford 2011. Singer dowodzi że w miarę postępu dziejów, człowiek rozszerzał krąg istot których wartości cenił jak własne.

106 P. Bayard, Jak rozmawiać o ksiq̨żkach, których się nie czytało?, Warszawa 2008, S. 63.

107 Przy dyskusjach o niej, warto wszak na pewno sięgnąć do artykułu I. Calvino Dlaczego warto czytać klasykę, „Odra” 1997, nr 9, s. 9-12. Mądre, wyrozumiałe słowa Włocha. 
założona produktywność dla celów dydaktycznych. W skrócie listę lektur determinowałyby odpowiedzi na pytanie: na których, dobrych artystycznie, utworach literatury najskuteczniej uczyć jej pełnego, głębokiego rozumienia?

Taka autodyrektywa dydaktyczna kwestionuje łatwą pokusę „naturalnej” redukcji kursu do analizy kilku(nastu) „hiperkanonicznych” tekstów literatury Okcydentu; choć i taka rama tematyczna dałaby się zaakceptować, o ile pozwalałaby studentowi na zdobycie pożądanych umiejętności. W moim przekonaniu powinien dominować jednak nie (tyle) nacisk na poznanie jakiegokolwiek mniej czy bardziej standardowego "kanonu”, co raczej intelektualne i metodyczne przysposobienie studentów do (nie tylko) jego kompetentnej lektury na podstawie wybranych utworów. Pomijając to, ich sensowny wybór wymaga po prostu jego zoptymalizowania pod presją kilku współoddziałujących czynników. Wspomniana dogodność dydaktyczna to raz; wiadomo też, że muszą one przylegać do ramy tematycznej. Ponadto uniwersytecki tryb zajęć narzuci w tej kwestii dodatkowe obiektywne ograniczenia bądź wymusi kompromisy. Coś trzeba bowiem wybrać, więc coś pominąć, zadowalająco wyważając selekcję względem chronologii i geografii, ewentualnie włączając więc do programu dzieła z odległych czasów i egzotycznych kultur108. Trzeba też zachować przemyślane proporcje między liczbą uwzględnionych tekstów a zakładanymi możliwościami ich głębokich analiz przy ograniczonych zasobach

108 To ekscytujący temat, który tutaj musimy pominąć. Zob. jednak przyczynek D. Damroscha Major Cultures and Minor Literatures, [w:] D. Damrosch (red.), Teaching World Literature, op. cit., s. 193-204. Idea autora polega m. in. na włączeniu do zajęć przedstawicieli peryferyjnych literatur poprzez przyporządkowanie ich do grup utworzonych według pewnych kryteriów historycznoliterackich. Np. kategoria „poeta narodowy" pozwalałaby na omówienie, obok Byrona, Puszkina czy Whitmana, takich twórców jak Wietnamczyk Nguyễn Du (1766-1820) czy Hindus Mirza Ghalib (17971869) i pisanych przezeń „ghazali/gazeli” (tworzonymi też przez Hafeza i naśladowanymi przez J. W. Goethego w Dywanie Zachodu i Wschodu). Taki sposób jukstapozycji autorów i tekstów z odległych kultur, osadzający ich we wspólnym kontekście dydaktycznym, wydaje się przystępny oraz wygodny w nauczaniu; więcej zaś odnośnych przykładów można wyszukać w książce D. Damroscha How to Read World Literature, op. cit. 
Szymon Gębuś - W kierunku pełni. O literaturze światowej...

czasowych; i oczywiście, liczba ta stanowi funkcję doboru konkretnych tekstów. Trzeba wreszcie zgodzić się na pewne kompromisy wobec objętości, np. li tylko na fragmenty z Prób Michela de Montaigne'a czy na omówienie, z całego arcydzieła Prousta, jedynie W stronę Swanna. Obszerne powieści XIX wieku: Wielkie nadzieje, Bracia Karamazow, Portret damy czy Nędznicy ozdobiłyby z pewnością każde konwersatorium, zajmując jednakże mnóstwo czasu, m. in. koniecznego dla rzetelnego przyswojenia ich treści przez studentów. Podobnie z tytanicznymi utworami bieżącego stulecia: 2666 Roberta Bolaño, Łaskawe Jonathana Littella, Wyznaję Jaume Cabré czy Małe życie Hanyi Yanagihary to majstersztyki, godne podziwu kreacje epickie (przy tym wręcz niewiarygodnie epatujące przemocą i moralnym złem); tyle że np. 2666 i Łaskawe to, w pierwszych wydaniach polskich, ponadtysiącstronicowe tomiszcza, i to też oczywiście należałoby uwzględnić.

I tutaj trzeba znaleźć salomonowe rozwiązanie; ważne wszak by wartościujące przywiązanie do „kanonicznych” czy rzekomo bardziej „wysokowartościowych” tytułów i ich objętości („,co obszerniejsze to prawdopodobnie godniejsze uwagi”) poddać realizacji celów dydaktycznych. Ucząc rozumienia literatury, możemy zatem z czystym sumieniem sięgnąc np. do rzeczy zminiaturyzowanych i skondensowanych a myślowo wciąż dostateczne bogatych i prowokujących. Weźmy Jeden dzień Iwana Denisowicza, skromna objętość, prosta jednowątkowa fabuła, banalny język tego bądź co bądź klejnotu XX wieku, ze złożoną problematyką i rozległymi odniesieniami, ewentualnie wprowadzającego do Archipelagu Gułag i twórczości łagrowej. Nad „kanonicznością” i objętością powinna więc panować idea skutecznego przygotowania studenta do radzenia sobie z wypowiedziami literackimi wszelkiej maści i różnej objętości.

Sądzę, że jej realizacji sprzyjałyby także poniższe propozycje, zgrupowane w 10 punktach. Bez pretensji do stworzenia w ten sposób samodzielnego, spójnego programu (co zostało wykluczone choćby zawężeniem listy niemal wyłącznie do literatury Zachodu) a wyłącznie jako luźny konglomerat propozycji do oportunistycznego wykorzystania, w zależności od potrzeb czy ramy tematycznej. Dodat- 
kowo ujednoliciłem je w trójsposób; respektując wymóg poziomu artystycznego (m. in. stąd częściowe wsparcie się laureatami Nagrody Bookera), skredytowując im produktywność dydaktyczną oraz, celem ukształtowania pewnego wachlarza sugestii w ramach chronologicznych, ograniczając się do prozy oraz (śladowo) dramatów i liryki XX i XXI wieku.

\section{Cormac McCarthy, Droga.}

Triumfator Nagrody Pulitzera w 2007 roku. Tematy: katastrofa naturalna, śmierć, miłość ojcowska, dobro wobec zła, wiara wobec zwątpienia, zaufanie, deformacja relacji rodzinnych, przetrwanie. Konwersatorium można zwieńczyć obejrzeniem wiernej ekranizacji z 2009 roku.

\section{Arundhati Roy, Bóg rzeczy małych.}

Zjawiskowa powieść indyjska; pretendująca do zwycięstwa w ewentualnym rankingu najwybitniejszych utworów światowej literatury pięknej minionych dwudziestu lat (1997-2016). Laureat Nagrody Bookera (1997). Tematy: rodzina, więzi/klasy społeczne, pamięć i przeszłość, miłość i seksualność. Dystyngowana proza ${ }^{109}$.

\section{Gabriel García Márquez, Miłość w czasach zarazy.}

Nadarcydzieło. Literacki love-show najprzedniejszej marki. Akcja w większości rozgrywa się (domyślnie) w pięknie położonej nad Morzem Karaibskim kolumbijskiej Cartagenie ${ }^{110}$, którą miałem okazję odwiedzić kilka lat temu. Spacerując wówczas wąskimi uliczkami tego przeuroczego miasta, sporo rozmyślałem o Florentino Arizie i jego obłąkańczym uczuciu do Ferminy Dazy; spoglądając zaś znad brzegu

109 Warto więc też posłuchać o niej na stronie http://www.learner.org/courses/ worldlit/the-god-of-small-things/watch/ [dostęp: 10.10.2017]. Wśród komentatorów autorka we własnej osobie oraz profesor David Damrosch.

110 Tam też osadzono główną akcję ekranizacji powieści i tamże w 2016 roku spoczęła, przewieziona z Meksyku, urna z prochami Márqueza. Cartagena miała dla pisarza szczególne znaczenie, nawet jeśli spędził w niej relatywnie niewiele czasu. 
Szymon Gębuś - W kierunku pełni. O literaturze światowej...

w intensywny lazur morza, wyobrażałem sobie statek ze złowieszczą żółtą flagą, płynący w nieskończenie długim rejsie.

Tematy: miłość, starzenie się, śmierć, małżeństwo, literatura i pisanie. Powieść zatem o niewyczerpanych wręcz kontekstach; jeśli weźmiemy choćby pierwszy z brzegu temat/motyw miłości w jesieni życia, od ręki znajdziemy - i to mówiąc wyłącznie o wybitnej prozie XX wieku - parantele np. u Kundery (Nieznośna lekkość bytu), Grassa (Wróżby kumaka) czy Kawabaty (Śpiq̨ce piękności) ${ }^{111}$. I tak dalej; temat miłości da się snuć do przesycenia. Poza więc główną lekturą (rolę której spełniłyby także np. Wichrowe Wzgórza, Anna Karenina czy Gargulec Andrew Davidsona) można wzbogacić konwersatorium o drobniejsze utwory oraz przyczynki z prac (popularno)naukowych, prowokując do spojrzenia na fenomen miłości jako jeden $\mathrm{z}$ fundamentalnych składników kultury humanistycznej oraz pole dociekań różnoźródłowych dyscyplin naukowych ${ }^{112}$.

Przykładowe pytania do lektury ${ }^{113}$ :

- W jaki sposób miłość i choroba łączą się ze sobą w powieści? Jak odnoszą się do siebie?

111 W 2004 roku do materii tej wrócił sam Márquez, w ostatniej książkowej prozie Rzecz o mych smutnych dziwkach, Warszawa 2005.

112 Prowadzący wybierze je według własnego uznania, wyłącznie więc przykładowo podaję takie tytuły: 1 . R. Carver, $O$ czym mówimy gdy mówimy o miłości, Izabelin 2006; świetna proza minimalistyczna. 2. A. Munro, Kocha, lubi, szanuje, Kraków 2015; zbiór uznawany niekiedy za najlepszy w dorobku noblistki. 3. Opowiadania Iwana Bunina. 4. R. Stiller, Wiersze o miłości, Katowice 2011; przekrój liryki miłosnej z różnych stron i epok. 5. R. Dunbar, The Science of Love, Hoboken 2012; o miłości z perspektyw antropologii, psychologii, (neuro)biologii i ewolucji, autora znanego m. in. ze słynnej „liczby Dunbara”. 6. J. Baines, The Science of Love, Nowy Jork 1993; pod identycznym tytułem Baines akcentuje psychologiczny wymiar miłości. 7. R. Barthes, Fragmenty dyskursu miłosnego, Warszawa 2011; z mnóstwem intrygujących odniesień do literatury pięknej. 8. B. Wojciszke, Psychologia miłości, Gdańsk 2009.

113 To pytania wyłącznie przykładowe, celujące w analizę tekstu. Nie są ani „najlepsze”, ani „jedyne możliwe”, a raczej odzwierciedlające, w niepełnym stopniu, moją subiektywną wizję dydaktycznego „rozbioru” utworu. Nie są też mojego autorstwa - zestawiając je korzystałem z kilku anglojęzycznych stron internetowych, jak www.gradesaver.com czy www.shmoop.com. Prócz wszak adaptacji językowej wybranych pytań, niekiedy je także, zazwyczaj nieistotnie, przeformułowywałem. 
- Gdy Tránsito Ariza żartobliwie daje do zrozumienia Florentinowi idącemu odwiedzić Ferminę, że wygląda jakby szedł na pogrzeb, ten odpowiada: „To prawie to samo” (s. 96) ${ }^{114}$. Dlaczego?

- Porównaj dwa samobójstwa: Jeremiasza de Saint-Amoura, przedstawione na początku powieści (s. 7 i n.), i Américy Vicuñi, byłej kochanki Florentina, wspomniane na końcu (s. 477). W jaki sposób różnią się ich samobójcze motywy? Dlaczego autor okala opowieść tymi wydarzeniami?

- W tle powieści napotyka się odniesienia do różnych przetaczających się wojen. Dlaczego wojny te zawsze znajdują się w oddaleniu od bohaterów i nie dotykają ich bezpośrednio? Jakie znaczenie dla powieści ma ten chwyt?

- Które utwory muzyczne wybrałbyś tworząc ścieżkę dźwiękową własnej wersji filmowej powieści? A które wybrałbyś jako „piosenki przewodnie" dla każdego z głównych bohaterów? (Do Florentina dobrze pasowałby bodaj np. przebój Lady Gagi Bad Romance).

- Jak wyglądałyby konta Facebookowe Florentina, Ferminy i doktora Urbino? Projektowanie ich przez studentów byłoby bliskim im sposobem m. in. na syntetyczne przedstawienie treści powieści.

- Krytycy czasami twierdzą, że kobiece postacie u Márqueza można zasadniczo sprowadzić do trzech typów: matriarchy, prostytutki oraz młodej i pięknej dziewicy. Czy można się z tym zgodzić? Czy któraś z powieściowych postaci kobiet transcenduje te stereotypy?

- Na ile Miłość w czasach zarazy jest powieścią „kolumbijską"? Dlaczego nigdy nie pojawia się w niej nazwa tego kraju?

\section{Literatura latynoamerkańska}

Pomijając arcyromans Márqueza, literatura latynoska oferuje wręcz bezbrzeżny rezerwuar tekstów, na bazie których można pokusić się o realizację mniej lub bardziej wymyślnych koncepcji. Mając np. do

\footnotetext{
${ }^{114}$ Numery stron według podanego w aneksie wydania: G. G. Márquez, Miłość w czasach zarazy, Warszawa 2016.
} 
Szymon Gębuś - W kierunku pełni. O literaturze światowej...

dyspozycji cztery semestry, można poświęcić jeden na przyjrzenie się wybranej, współczesnej literaturze narodowej. Weźmy Chile, przepiękny kraj o intrygującym a u nas praktycznie nieznanym pisarstwie. Celem przystępnego a treściwego wprowadzenia w nie, można zacząć od łatwo uchwytnych interpretacyjnie opowiadań Luisa Sepúlvedy Przegapienia, króciutkich perełek o straconych w życiu szansach; uniwersalnych w wymowie a zarazem, w większości solidnie osadzonych w chilijskich realiach topograficznych. Sepúlvedę znamy także ze zbioru Lampa Aladyna, obu zaś zbiorom artystycznie co najmniej dorównują świetne Historias marginales, z galerią arcyciekawych bohaterów; nie zostały one jednak przełożone na polski. Przetłumaczono za to uroczą Opowiadaczkę filmów Hernána Rivery Leteliera ${ }^{115}$ i niezgorsze Opowieści z dalekiego południa Francisca Coloanego ${ }^{116}$. Po nich można spróbować komiksów ze słynnej serii Incal Alejandra Jodorovsky'ego ${ }^{117}$, najbardziej szalonego na świecie filmowego reżysera, okazjonalnie pisarza, by następnie sięgnąć po sztukę Ariela Dorfmana (zmuszonego do emigracji po przewrocie w 1973 roku) Śmierć i dziewczyna ${ }^{118}$, sfilmowaną przez Romana Polańskiego. Wreszcie przejść do pisarstwa Gabrieli Mistral, Isabeli Allende, Pabla Nerudy, Roberta Bolaño czy Josego Donoso.

Tyleż specyficzny co frapujący nurt współczesnej literatury latynoskiej przedstawia powieść dyktatorska (hiszp. novela del dictador), zakorzeniona w (po)boliwarowskich historiach dyktatur południowoamerykańskiego lądu. Zjawisko godne uwagi $\mathrm{z}$ trzech względów: tematyki jako takiej, artystycznej maestrii utworów oraz postaci ich twórców, gatunek ten praktykowali bowiem m. in. wybitni autorzy boomu latynoamerykańskiego jak Mario Vargas Llosa (Święto Ko-

115 H. R. Letelier, Opowiadaczka filmów, Warszawa 2012.

116 F. Coloane, Opowieści z dalekiego południa, Warszawa 2003.

${ }_{117}$ A. Jodorowsky, J. Giraud, Incal, Łódź 2015. To jedna z kilku części sagi o Incalu.

118 Opublikowaną w „Dialogu”: A. Dorfman, Śmierć i Dziewczyna, „Dialog” 1992, nr 10, s. 41-67. W tym samym numerze godny polecenia autokomentarz: A. Dorfman, Zakłócam spokój, s. 143-145. 
zła) ${ }^{119}$, Alejo Carpentier (Szaleństwo i metoda) czy García Márquez (Jesień patriarchy i Generał w labiryncie); dowolny z tych tekstów zapewne dobrze „przyjąłby się” na zajęciach. Kuty na cztery nogi prowadzący mógłby jednak pójść o krok dalej i, co stanowiłoby dla niego samego niewątpliwy komplement, wziąć na tapet powieść Ja, Najwyższy Augusto Roy Bastosa, uznawaną za najwybitniejszą w całej literaturze paragwajskiej. Sprostanie jej wymaga jednak sporej przenikliwości interpretacyjnej, biegłej zdolności wykrywania/nadawania sensów oraz bardzo przyzwoitej (szczegółowej) orientacji w odnośnej historii Paragwaju.

5. L. Tołstoj Śmierć Iwana Iljicza, Albert Camus Obcy i Upadek, Jean Paul-Sartre Mdłości i dramat Przy drzwiach zamkniętych.

Niewielka objętość tekstów pozwoliłaby na ich potraktowanie w jednym bloku. W poznaniu zrębów egzystencjalizmu powinny pomóc studentom prace Existentialism. A Beginner's Guide Thomasa E. Wartenberga ${ }^{120}$ oraz Existentialism for Dummies Christophera Panzy i Gregory Gale'a121. Warto przy okazji nawiązać do idei egzystencjalistycznych w myśli Nietzschego czy Kierkegaarda.

\section{Italo Calvino, Jeśli zimowq nocą podróżny.}

Jako kliniczny przykład poetyki postmodernistycznej. Jako główna kontrpropozycja - 49 idzie pod młotek Thomasa Pynchona, zaś postmodernizm „na ulgowo” to choćby Rzeźnia numer 5 Kurta Vonneguta, Złodziejka książek Marcusa Zusaka czy Imię róży Umberto Eco. W podstawowe idee tego nurtu wprowadzi słuchaczy Postmodernism for beginners Jima Powella122, ale jeszcze lepiej skorzystać z rozdziału

119 Warto też obejrzeć ekranizację tej powieści, z Isabellą Rossellini w roli Uranii Cabral.

120 T. E. Wartenberg, Existentialism. A Beginner's Guide, Londyn 2008, kilkakrotnie wznawiana.

121 C. Panza, G. Gale, Existentialism for Dummies, Indianapolis 2008.

122 J. Powell, Postmodernism for beginners, Danbury 1998. 
Szymon Gębuś - W kierunku pełni. O literaturze światowej...

o postmodernizmie w An Introduction to Literature, Criticism and Theory Bennetta i Royle'a.

\section{Yann Martel, Życie Pi.}

Kolejna opowieść nagrodzona Bookerem (2002); pomysłowa rozprawa o nadziei, Bogu, religii, literaturze i kreowaniu narracji. Także dość postmodernistyczna, gdy rozważyć jedną z jej pierwszoplanowych idei (wersje/opowieści o rzeczywistości dominują nad nią) i z atrakcyjnymi kontekstami (Robinson Crusoe, Boska komedia, Max e os felinos brazylijskiego pisarza Moacyra Scliara i inne). Na koniec warto obejrzeć plastyczną adaptację w reżyserii Anga Lee123.

\section{Anthony Burgess, Mechaniczna pomarańcza lub Nakręcana poma-} rańcza, zależnie od Roberta Stillera wersji tłumaczenia124.

Tematy: wartość wolnej woli, zło etyczne a sztuka, dualność i dualizmy jako model(e) rzeczywistości, atrakcyjność zła. Zajęcia można spuentować obejrzeniem Kubrickowskiej ekranizacji, koniecznie z wyjaśnieniem kwestii pominiętego w niej książkowego zakończenia125.

${ }^{123} \mathrm{~A}$ prócz niej wywiad z autorem: https://www.youtube.com/watch?v=ZFCqLU GKi5c [dostęp: 10.10.2017] oraz jego wypowiedź o okolicznościach pisania powieści: https://medium.com/@Powells/how-i-wrote-life-of-pi-6ffe1c0177ac [dostęp: 10.10. 2017].

124 Wystarczy oczywiście jedna; preferowałbym „wersję R” (Mechaniczna pomarańcza).

125 Warto też skorzystać z opracowania ukrytych w filmie drobnych aluzji i dodatkowych znaczeń (dostępnego na stronie https://www.youtube.com/watch?v=KufUq 4Avhds, [dostęp: 10.10.2017]), które podczas oglądania najprawdopodobniej by widzom umknęły. Np. powtarzalna obecność czterech elementów: czterech członków gangu, cztery figurki Chrystusa w pokoju Alexa, konfrontacja z czterema przedstawicielami władzy czy widok starego filmu z czterema żołnierzami hitlerowskimi włamującymi się do cudzego domu. Albo Alex eskortowany przez policjantów z numerami 665 i 667 na pagonach, co zostawia dlań, idącego pośrodku, liczbę 666, itd. Prowadzący może np. na chwilę przerywać projekcję filmu i wskazywać na te ukryte drobnostki lub naprowadzać na nie studentów. 
9. Guru literatury latynoskiej i bodaj najbardziej frapującemu mnie autorowi - Jorge Luisowi Borgesowi - przysługuje osobne potraktowanie. Sugestie ${ }^{126}$ :

- Ogród o rozwidlających się ścieżkach

- Biblioteka Babel

- Borges i ja

- Ewangelia według świętego Marka127

- O ścisłości w nauce lub Pierre Menard, autor Don Kichota.

- Poza tym ewentualnie liryka, wedle uznania128. I przykładowe (nieprzyzwoicie niekompletne) pytania do Ogrodu o rozwidlajqcych się ścieżkach:

- Dywagując o fenomenie czasu, Stephen Albert wspomina Isaaca Newtona i Arthura Schopenhauera (s. 89) ${ }^{129}$. Co obaj filozofowie myśleli o czasie? Jak znajomość ich myśli wpływa na rozumienie opowiadania Borgesa?

- Znajdź w opowiadaniu aluzje do utworów literackich oraz postaci/wydarzeń historycznych. W jaki sposób znajomość tych utworów i wydarzeń zmienia jego rozumienie?

- Ile różnych tekstów pojawia się w opowiadaniu? (Można nakreślić rodzaj diagramu obrazującego na jakie sposoby pisma te łączą się, zachodzą na siebie itp.). Dlaczego Borges pisze także o tekstach nieistniejących empirycznie?

- Tylko w nielicznych opowiastkach Borgesa znajdziemy bohaterów kobiecych. Na ile Ogród o rozwidlających się ścieżkach byłby odmienny gdyby główni bohaterowie byli kobietami?

126 Większość z nich można znaleźć w zbiorze: J. L. Borges, Opowiadania, Kraków 1978, zaś dwa (Borges i ja, O ścisłości w nauce) w: J. L. Borges, Twórca, Warszawa 1974.

127 To opowiadanie zekranizowano w krótkim metrażu, zob. https://www.youtube. com/watch?v=KwXneCUTeuk (oryginalna wersja hiszpańska) [dostęp: 10.10.2017].

128 Jej przyzwoity polski wybór (31 wierszy) zawarła Krystyna Rodowska w solidnej pracy Umocz wargi w kamieniu. Przekłady z poetów latynoamerykańskich, Wrocław 2011.

${ }^{129}$ Numer strony według podanego w aneksie wydania: J. L. Borges, Opowiadania, Kraków 1978. 
Szymon Gębuś - W kierunku pełni. O literaturze światowej...

- 0 czym mówią teoria chaosu i idea bifurkacji? W jaki sposób można je połączyć z treścią opowiadania?

Cóż - historyjki Borgesa wyzywają intelekt. Argentyńczyk pasjami wtłacza w nie zagadki, łamigłówki, niejasne odwołania i obcojęzyczne frazy. W dodatku, ze swoją niebywałą erudycją zawsze jakby o dwa kroki wyprzedza czytelnika. I - coś w tym jest! Borges uchodził za „cudowne dziecko”, m. in. publikując w wieku niespełna 11 lat (!) w argentyńskiej prasie tłumaczenie utworu Oscara Wilde’a na hiszpański130. Był też jednym z najbardziej oczytanych ludzi świata, laureatem honorowych doktoratów Oxfordu czy Sorbony, posługiwał się kilkoma językami. Nadpisarz, posągowa postać wielkiej literatury - którą warto uhonorować wzmożoną uwagą.

\section{Richard Flanagan, Ścieżki Północy.}

Jeszcze jeden błysk nagrody Bookera (2014). Gorzka opowieść o miłości i wojennym piekle, okrzyknięta „australijską Wojnq i pokojem". Poniżej, kilka przykładowych ćwiczeń (które nauczyciel może urozmaicać i zróżnicowanie w nich uczestniczyć) plus propozycje literatury uzupełniającej. Ćwiczenia131:

- Studenci, w 4 osobnych grupach, szkicują losy i nakreślają cechy charakteru (wady/zalety) jednego z bohaterów: Dorrigo Evansa, Tenji Nakamury, Amy Mulvaney i Elli Lansbury. Następnie „grupa Dorriga” łączy się z „grupą Nakamury”, zaś „grupa Mulvaney” z "grupą Lansbury”. Połączone grupy przedstawiają sobie wzajemnie „swoich” bohaterów, porównując ich i wskazując na zróżnicowanie losów, zachowań i cech charakteru.

130 Chodzi o przekład uroczej opowiastki Wilde’a Szczęśliwy książę. Ukazało się 25 czerwca 1910 roku w lokalnej gazecie El País w Buenos Aires. W autobiografii Borges podaje, że przetłumaczył ten tekst mając „jakieś dziewięć lat” (J. L. Borges Autobiografia, Warszawa 2002, s. 17). Może to wyjaśniać pojawianie się niekiedy błędnej informacji, że opublikował to tłumaczenie w takim właśnie wieku; de facto, w chwili prasowej publikacji tego tekstu miał 11 lat bez 2 miesięcy.

131 Zaczerpnąłem je $\mathrm{z}$ australijskiej strony: https://readingaustralia.com.au/ lesson/the-narowi-road-to-the-deep-north/ [dostęp: 10.10.2017]. Łatwo zauważyć, że wszystkie prowokują kreatywność ćwiczących. 
To zajęcie pomagające zrozumieć, w jaki sposób Flanagan konstruuje kontrastujące charaktery (ang. character foils). Może ono zarazem służyć jako wstęp do dyskusji na tematy dobra i zła, znaczenia określeń „dobra/zła kobieta” i „dobry/zły mężczyzna” oraz rozważań na temat czy i jak można odkupić swoje życiowe winy.

- Studenci porównują okładki kilkunastu zagranicznych edycji powieści ${ }^{132}$, ustalając: jakie widoki powtarzają się na nich? Co mogą reprezentować? Następnie indywidualnie lub w małych zespołach przedstawiają (opisują i/lub szkicują) propozycje własnych okładek i prezentują je na forum grupy.

- Dokładna lektura fragmentu od słów: „Wśród mazi z błota...” do słów: „Przykro mi, że sprawiam panu zawód” (s. 254-255) ${ }^{133}$. Studenci zaznaczają powtarzające się $\mathrm{w}$ nim słowa i myśli, by potem przedyskutować ich wpływ na lekturę.

Z tekstów zbliżonych tematycznie, można polecić reminiscencje byłych więźniów japońskich obozów pracy: Prisoner of Japan: A Personal War Diary Singapore, Siam and Burma, 1941-1945 Harolda Atcherleya ${ }^{134}$, Railroad of Death Johna Coasta ${ }^{135}$ oraz Droge do zapomnienia Erica Lomaxa ${ }^{136}$. Ponadto Most na rzece Kwai Pierre Boullego ${ }^{137}$ i Króla szczurów Jamesa Clavella138.

Wreszcie dodatkowe (oprócz wzmiankowanych wcześniej), wyimkowe propozycje z krótszej prozy:

\footnotetext{
132 Można je znaleźć na stronie: https://www.goodreads.com/work/editions/ 25086415-the-narrow-road-to-the-deep-north [dostęp: 10.10.2017].

133 Numery stron według podanego w aneksie wydania: R. Flanagan, Ścieżki Pótnocy, Kraków 2015.

134 Sir H. Atcherley, Prisoner of Japan: A Personal War Diary Singapore, Siam and Burma, 1941-1945, Cirencester 2015.

135 J. Coast, Railroad of Death, Newcastle upon Tyne 2014. Jedno z pierwszych wspomnień z katorgi na Kolei Śmierci, opublikowane (pierwodruk) w 1946 roku.

${ }^{136}$ E. Lomax, Droga do zapomnienia, Kraków 2014. Na bazie książki nakręcono znany film z udziałem $m$. in. Nicole Kidman.

137 P. Boulle, Most na rzece Kwai, Warszawa 2002.

138 J. Clavell, Król szczurów, Kraków 2013.
} 
Szymon Gębuś - W kierunku pełni. O literaturze światowej...

1. Bohumil Hrabal, Pociagi pod specjalnym nadzorem plus oscarowa ekranizacja autorstwa Jiřiego Menzla. Tegoż pisarza, Zbyt głośna samotność - o znajdowaniu sensu wśród chaosu życia ${ }^{139}$.

2. Iwan Bunin, wybór z opowiadań; wystarczą zbiory Gramatyka miłości i inne opowiadania oraz Pamiętny bal i inne opowiadania ${ }^{140 .}$ Warto też przyjrzeć się utworom Cortázara (np. rewelacyjnej Ciągłości parków ${ }^{141}$ ), Poego, Czechowa, Asimova a także wydanym u nas w 2016 roku zbiorom: Centuria Giorgio Manganelliego oraz 10 grudnia George Saundersa.

3. Etiudy i marginalia mogą pomóc w wdrożeniu się w twórczość mistrzów sławnych z okazałych powieści. W przypadku np. Joyce’a, sprawdzą się w tej roli opowiadania z tomu Dublińczycy; warte uwagi choćby Ewelina, Przypadek godny ubolewania i Zmarli.

\section{Zakończenie}

Być może taka wszechstronnie przemyślana i rozsądnie zaplanowana, ogólnokierunkowa rewitalizacja literatury światowej, połączona $\mathrm{z}$ ewentualnym przeformułowaniem nauczania literatury niemieckiej, choćby niewielkim krokiem poprowadziłaby nas w kierunku nowoczesnego ukierunkowania studiów germanistycznych, odpowiadających dzisiejszym wymogom: wszechstronnie zatem kształcących, wpajających praktyczną, aktualną wiedzę i przydatne umiejętności ${ }^{142}$. Możliwe, że zarazem bodaj minimalnie mogłaby ona odmienić zanadto już u nas rozpleniony tzw. „pasażowy”143 styl „studiowania”,

\footnotetext{
139 Godna polecenia jest podana w bibliografii edycja Wydawnictwa Literackiego z 1993 roku, z dołączonym Adagio Lamentoso i cennymi uwagami tłumacza.

140 Miłośnikom autora spodoba się też zapewne sympatyczna monografia L. B. Grzeniewskiego pt. Iwan Bunin, Warszawa 1982.

141 Opublikowanej m. in. w zbiorze J. Cortázar, Opowiadania, Warszawa 1994.

142 Por. godną podziwu acz boleśnie utopijną wizję Ł. Abramowicza i M. Miąskiewicza z artykułu Czy studia muszq być nudne?, "Gazeta Wyborcza” 12.02.2008, s. 12.

143 „Uniwersytet pasaż” to miejsce jedynie chwilowego pobytu przy okazji przejścia z domu do pracy i z pracy do domu, z pracy bądź domu na inny fakultet i z innego fakultetu, na kursy i z kursów. „Uniwersytet pasaż” nie jest miejscem kształcenia, lecz miejscem zaliczania punktów koniecznych do uzyskania dyplomu i budowy CV pod
} 
nadając studiom germanistycznym w większym stopniu walory wyzywającej intelektualnej przygody. Choćby $\mathrm{z}$ tych ważkich przecież powodów warto zastanowić się nad wznieceniem środowiskowej, merytorycznej dyskusji nad przedstawionym tutaj zaledwie w sposób zalążkowy tematem. Dyskusji autorefleksyjnej i konstruktywnej, która u nas wciąż jeszcze nie zaistniała w zasługującym na to wymiarze.

\section{Aneks - spis lektur}

Niniejszy aneks zawiera bibliograficzne zestawienie utworów literackich, uznanych za mniej lub bardziej stosowne do analizy na zajęciach lub wspomnianych w tekście przy różnych okazjach.

Alighieri D., Boska komedia, Wydawnictwo Pasaże, Nowy Sącz 2015.

Bastos A. R., Ja, Najwyższy, Wydawnictwo Literackie, Kraków 1982.

Bolaño R., 2666, Muza, Warszawa 2012.

Borges J. L., Autobiografia, Prószyński i Sk-a, Warszawa 2002.

Borges J. L., Opowiadania, Wyawnictwo Literackie, Kraków 1978.

Borges J. L., Twórca, Czytelnik, Warszawa 1974.

Brontë E. J., Wichrowe Wzgórza, Świat Książki, Warszawa 2015.

Bunin I., Gramatyka miłości i inne opowiadania, Czytelnik, Warszawa 1972.

Bunin I., Pamiętny bal i inne opowiadania, KAW, Warszawa 1992.

Burgess A., Mechaniczna pomarańcza, vis-à-vis/Etiuda, Kraków 2009.

Burgess, A., Nakręcana pomarańcza, vis-à-vis/Etiuda, Kraków 2013.

kątem rynku pracy. „Uniwersytet pasaż” pływa w „płynnej nowoczesności”. Wszystko jest w nim chwilowe, zmienne i płytkie. Można jedynie zastanawiać się, czy to brak zaangażowania, które tworzy tożsamość angażujących się i tożsamość celu zaangażowania jest przyczyną „płynnej nowoczesności”, w tym „uniwersytetu pasażu”, czy też odwrotnie, to płynna nowoczesność i stanowiący jej część „uniwersytet pasaż” powoduje brak głębszego zaangażowania, a przez to rozmycie zarówno tożsamości słabo, chwilowo i powierzchownie zaangażowanych, jak i celów, do których dążą. W „uniwersytecie pasażu” wszystko jest zmienne i chwilowe (ustawy, rozporządzenia, systemy ocen, autorytety, notatki studenckie krążące w Internecie)". Tadeusz Gadacz, Studia i odpowiedzialność, „Znak” 2013, nr 4, s. 84. Tytuł nawiązujący do eseju Maxa Horkheimera z 1954 roku, gdzie mowa także m. in. o kwestiach wszechstronnego kształcenia (humanistycznego); M. Horkheimer, Odpowiedzialność i studia, „Kronos" 2011, nr 2, s. 237-248. 
Szymon Gębuś - W kierunku pełni. O literaturze światowej...

Carpentier A., Szaleństwo i metoda, Czytelnik, Warszawa 1980.

Cabré J., Wyznaję, Marginesy, Warszawa 2013.

Calvino I., Jeśli zimowq nocą podróżny, W.A.B., Warszawa 2012.

Camões L. V. de, Luzytanie, Wydawnictwo Literackie, Kraków 1995.

Camus A., Obcy. Dżuma. Upadek, Wydawnictwo Literackie, Kraków 1972.

Carver R. O czym mówimy kiedy mówimy o miłości, Świat Literacki, Warszawa 2006.

Chang E., Ostrożnie, pożądanie, W.A.B., Warszawa 2008.

Chang E., Miłość jak pole bitwy, W.A.B., Warszawa 2008.

Coloane F., Opowieści z dalekiego południa, Noir sur Blanc, Warszawa 2003.

Cortázar J., Opowiadania, Muza, Warszawa 1994.

Davidson A., Gargulec, W.A.B., Warszawa 2009.

Defoe D., Robinson Crusoe, Greg: Kraków 2010.

Dickens Ch., Wielkie nadzieje, Prószyński i S-ka, Warszawa 2013.

Dorfman A., Śmierć i dziewczyna, „Dialog” 1992, nr 10.

Dostojewski F., Bracia Karamazow, Wydawnictwo Dolnośląskie, Wrocław 1998.

Eco U., Imię róży, Noir sur Blanc, Warszawa 2012.

Flanagan R., Ścieżki Północy, Wydawnictwo Literackie, Kraków 2015.

Goethe J. W., Dywan Zachodu i Wschodu, PIW, Warszawa 1963.

Gogol M., Pamiętnik wariata, Książka i Wiedza, Warszawa 1968.

Grass G., Wróżby kumaka, Polnord-Oskar, Gdańsk 1999.

Homer, Odyseja, Czytelnik, Warszawa 1989.

Hrabal B., Pociagi pod specjalnym nadzorem, Wydawnictwa Artystyczne i Filmowe, Warszawa 1985.

Hrabal B., Zbyt głośna samotność, Wydawnictwo Literackie, Kraków 1993.

Hugo W., Nędznicy, Bellona, Warszawa 2014.

James H., Portret damy, Prószyński i S-ka, Warszawa 2014.

Jodorovsky A., Giraud J., Incal, Scream Comics, Łódź 2015.

Joyce J., Dublińczycy, Oskar, Warszawa 1991.

Joyce J., Ulisses, Znak, Kraków 2013.

Kafka F., Opowieści i przypowieści, [w tym Przemiana], PIW, Warszawa 2016.

Kawabata Y., Śpiq̨ce piękności. Tysiq̨c żurawi, Muza, Warszawa 2002.

Kundera M., Nieznośna lekkość bytu, W.A.B., Warszawa 2013.

Lahiri J., Imiennik, Prószyński i S-ka, Warszawa 2007.

Lahiri J., Nieoswojona ziemia, Albatros, Warszawa 2010.

Lahiri J., Tłumacz chorób, Albatros, Warszawa 2010. 
Lahiri J., Zagubieni wśród hiacyntów, Albatros, Warszawa 2015.

Letelier H. R., Opowiadaczka filmów, Muza, Warszawa 2012.

Lewicki T. (red.), Księga tysiq̨ca i jednej nocy, PIW, Warszawa 1973.

Littell J., Łaskawe, Wydawnictwo Literackie, Kraków 2008.

Llosa M. V., Święto Kozła, Rebis, Poznań 2002.

Manganelli G., Centuria. Sto krótkich powieści rzek, PIW, Warszawa 2016.

Márquez G. G., Generał w labiryncie, Muza, Warszawa 2017.

Márquez G. G., Jesień patriarchy, Muza, Warszawa 2010.

Márquez G. G., Miłość w czasach zarazy, Muza, Warszawa 2016.

Márquez G. G., Morze utraconych opowiadań i inne felietony, Muza, Warszawa 2000.

Márquez G. G., Nie wygłoszę tu mowy, Muza, Warszawa 2011.

Márquez G. G., Rzecz o mych smutnych dziwkach, Muza, Warszawa 2005.

Martel Y., Życie Pi, Albatros, Warszawa 2013.

McCarthy C., Droga, Wydawnictwo Literackie, Kraków 2008.

Montaigne M. de, Próby, PIW, Warszawa 1985.

MunroA., Kocha, lubi, szanuje, Wydawnictwo Literackie, Kraków 2015.

Pamuk O., Nazywam się Czerwień, Wydawnictwo Literackie, Kraków 2015.

Popol Vuh. Księga Rady Narodu Quiché, PIW, Warszawa 1980.

Proust M., W stronę Swanna, MG, Warszawa 2013.

Pynchon T., 49 idzie pod młotek, Wydawnictwo Literackie, Kraków 2009.

Pynchon T., Tęcza grawitacji, Prószyński i S-ka, Warszawa 2006.

Rodowska K., Umocz wargi w kamieniu. Przekłady z poetów latynoamerykańskich, Biuro Literackie, Wrocław 2011.

Roy A., Bóg rzeczy małych, Zysk i S-ka, Poznań 1997.

Sartre J. P., Dramaty: Muchy. Przy drzwiach zamkniętych. Ladacznica z zasadami. Niekrasow, PIW, Warszawa 1956.

SartreJ. P., Mdłości, Zielona Sowa, Warszawa 2005.

Saunders G., 10 grudnia, W.A.B., Warszawa 2016.

Sepúlveda L., Historias marginales, Seix Barral, Barcelona 2000.

Sepúlveda L., Lampa Aladyna i inne opowiadania na przekór niepamięci, Noir sur Blanc, Warszawa 2011.

Sepúlveda L., Przegapienia, Noir sur Blanc, Warszawa 2005.

Scliar M., Max e os felinos, L\&PM, Porto Alegre 1981.

Shikibu M., The Tale of Genji, Viking, Nowy Jork 2002.

Sołżenicyn A., Archipelag Gułag. 1918-1956, Rebis, Poznań 2008.

Sołżenicyn A., Jeden dzień Iwana Denisowicza, Iskry, Warszawa 1989. 
Szymon Gębuś - W kierunku pełni. O literaturze światowej...

Soyinka W., Death and the King's Horseman, Turtleback, St. Louis 2002.

Stiller R., Wiersze o miłości. Antologia kontrowersyjna. Także i do śpiewu, Kos, Katowice 2011.

Stiller R., Gilgamesz. Epos babiloński i asyryjski ze szczq̨tków odczytany i uzupełniony także pieśniami szumerskimi przez Roberta Stillera, vis-à-vis/ Etiuda, Kraków 2013.

Tołstoj L., Anna Karenina, Znak, Kraków 2012.

Tołstoj L., Śmierć Iwana Iljicza, PIW, Warszawa 1960.

Vonnegut K., Rzeźnia numer pięć, Albatros, Warszawa 2013.

Wallace D. F., Infinite Jest, Little Brown, Nowy Jork 1996.

Wilde 0., Bajki, [w tym Szczęśliwy książę], Letter-Perfect International, Warszawa 1993.

Wolter, Kandyd, Greg, Kraków 2012.

Xun L., Opowiadania, Wydawnictwo Akademickie Dialog, Warszawa 2015.

Yanagihara H., Małe życie, W.A.B., Warszawa 2016.

Zusak M., Złodziejka książek, Nasza Księgarnia, Warszawa 2014.

\section{Bibliografia:}

Abramowicz Ł., Miąskiewicz M., Czy studia muszą być nudne?, „Gazeta Wyborcza" 12.02.2008.

Atcherley H., Prisoner of Japan: A Personal War Diary Singapore, Siam and Burma, 1941-1945, Memoirs Publishing: Cirencester 2015.

Baines J., The Science of Love, John Baines Inst, Nowy Jork 1993.

Barry P., Beginning Theory. An Introduction to Literary and Cultural Theory, Manchester University Press, Manchester - Nowy Jork 1995.

Barthes R., Fragmenty dyskursu miłosnego, Aletheia, Warszawa 2011.

Bereza H., Proza z importu. Szkice literackie, Czytelnik, Warszawa 1979.

Bayard P., Jak rozmawiać o ksiq̨żkach, których się nie czytało?, PIW, Warszawa 2008.

Beckett S., Wierność przegranej, Znak, Kraków 1999.

Bennett A., Royle N., An Introduction to Literature, Criticism and Theory. Third Edition, Pearson/Longman, Harlow 2004.

Bloom H., The Western Canon. The Books and School of the Ages, Harcourt Brace, Nowy Jork - San Diego - Londyn 1994.

Booker Ch., The Seven Basic Plots: Why We Tell Stories, Bloomsbury Publishing, Londyn 2004. 
Boulle P., Most na rzece Kwai, K.E. Liber, Warszawa 2002.

Burzyńska A., Markowski M. P., Teorie literatury XX wieku. Podręcznik, Znak, Kraków 2006.

Calvino I. Dlaczego warto czytać klasykę, „Odra”1997, nr 9.

Calvino I., Wykłady amerykańskie. Sześć przypomnień dla przyszłego tysiąclecia, Świat Literacki, Warszawa 2009.

Carter D., How to Win the Nobel Prize in Literature. A Handbook for the Would-be Laureate, Hesperus Press Limited, Londyn 2012.

Clavell J., Król szczurów, vis-a-vis/Etiuda, Kraków 2013.

Coast J., Railroad of Death, Myrmidon Books, Newcastle upon Tyne 2014.

Coetzee J. M., Dziwniejsze brzegi. Eseje literackie 1986-1999, Znak, Kraków 2008.

Coetzee J. M., Wewnętrzne mechanizmy. Eseje literackie 2000-2005, Znak, Kraków 2012.

Compagnon A., Demon teorii. Literatura a zdrowy rozsqdek, słowo / obraz terytoria, Gdańsk 2010.

Cortázar J., O literaturze. Wykłady w Berkeley, 1980, Wydawnictwo w Podwórku, Gdańsk 2016.

Czapliński P., Literatura światowa i jej figury, „Teksty Drugie. Teoria literatury. Krytyka. Interpretacja" 2014, nr 4.

Czapski J., Czytając, Znak, Kraków 2015.

Damrosch D., How to Read World Literature, Wiley \& Blackwell, Chichester 2009.

Damrosch D. (red.), Teaching World Literature, The Modern Language Association of America, Nowy Jork 2008.

Deptuła B., Literatura od kuchni, W.A.B., Warszawa 2013.

Dirda M., Classics for Pleasure, Harcourt, Inc., Orlando 2007.

Dirda M., Readings: Essays and Literary Entertainments, Indiana University Press, Bloomington 2000.

Dorfman A., Zakłócam spokój, „Dialog” 1992, nr 10.

Dunbar R., The Science of Love, Wiley, Hoboken 2011.

Eco U., O Bibliotece, Świat Książki, Warszawa 2007.

Eco U., O literaturze, Muza, Warszawa 2003.

Eco U., Szaleństwo katalogowania, Rebis, Poznań 2009.

Eco U., Rorty R., Culler J., Brooke-Rose Ch., Interpretacja i nadinterpretacja, Znak, Kraków 2008.

Eliot T. S., Szkice literackie, Instytut Wydawniczy PAX, Warszawa 1963. 
Szymon Gębuś - W kierunku pełni. O literaturze światowej...

Espmark K., Der Nobelpreis für Literatur. Prinzipien und Bewertungen hinter den Entscheidungen, Vandenhoeck und Ruprecht, Getynga 1988.

Ercolino S., The Maximalist Novel. From Thomas Pynchon's Gravity's Rainbow to Roberto Bolano's 2666, Bloomsbury Academic, Londyn 2014.

Fadiman A., Ex Libris. Wyznania czytelnika, Świat Literacki, Warszawa 2004.

Fadiman A. (red.), Rereadings, Farrar, Straus and Giroux, Nowy Jork 2005.

Federman R., Czym sq powieści eksperymentalne i dlaczego ich się nie czyta?, „Literatura na Świecie” 1984, nr 9.

Floryan W. (red.), Dzieje literatur europejskich, PWN, Warszawa 1977-1991.

Foster T. C., How To Read English Like a Professor. A Lively and Entertaining Guide to Reading Between the Lines, HarperCollins, Nowy Jork 2003.

Fuentes C., W to wierzę, Świat Książki, Warszawa 2003.

Gadacz T., Studia i odpowiedzialność, „Znak” 2013, nr 4.

Gelfert H.-D., Was ist gute Literatur? Wie man gute Bücher von schlechten unterscheidet, C. H. Beck, Monachium 2010.

Gelfert H.-D., Wie interpretiert man einen Roman, Philipp Reclam, Stuttgart 2006.

Gondowicz J., Duch opowieści, Nisza, Warszawa 2014.

Grzeniewski L. B., Iwan Bunin, Czytelnik, Warszawa 1982.

Horkheimer M., Odpowiedzialność i studia, „Kronos” 2011, nr 2.

Huntington S. P., Wojna cywilizacji?, „Res Publica Nowa” 1994, nr 2(65).

Husserl E. Kryzys europejskiego człowieczeństwa a filozofia, Aletheia, Warszawa 1993.

Johnson R. Studying Fiction. A guide and study programme, Manchester University Press, Manchester - Nowy Jork 1994.

Kahler E., Przeobrażenia nowoczesnej powieści, „Pamiętnik Literacki” 1970, nr 3.

Kalanithi P., Jeszcze jeden oddech, Wydawnictwo Literackie, Kraków 2016.

Kayser W., Powstanie i kryzys powieści nowoczesnej, „Przegląd Humanistyczny" 1960, nr 1.

Kelly S., Księga ksiąg utraconych, W.A.B., Warszawa 2008.

Kola F. A., Między komparatystykq literackq a literaturq światowa, „Teksty Drugie. Teoria literatury. Krytyka. Interpretacja" 2014, nr 4.

Kronenberg A., Geopoetyka. Zwiq̨zki literatury i środowiska, Wydawnictwo Uniwersytetu Łódzkiego, Łódź 2015.

Kundera M., Sztuka powieści. Esej, Czytelnik, Warszawa 1998.

Kundera M., Zasłona. Esej w siedmiu częściach, PIW, Warszawa 2006. 
Kundera M., Zdradzone testamenty. Esej, Grupa Wydawnicza Foksal, Warszawa 2015.

Lamping D., Die Idee der Weltliteratur. Ein Konzept Goethes und seine Karriere, Kröner, Stuttgart 2010.

Lamping D. (red.), Meilensteine der Weltliteratur. Von der Aufklärung bis in die Gegenwart, Kröner, Stuttgart 2015.

Lem S., Filozofia przypadku. Literatura $w$ świetle empirii, Wydawnictwo Literackie, Kraków 1968.

Llosa M. V., La verdad de las mentiras, Penguin Random House Grupo Editorial, Barcelona 2015.

Llosa M. V., O czytaniu i pisaniu. Wybór eseistyki, Wydawnictwo w Podwórku, Gdańsk 2017.

Llosa M. V., Prawda kłamstw. Eseje o literaturze, Rebis, Poznań 1999.

Lomax E., Droga do zapomnienia, Znak Literanova, Kraków 2014.

Löffler S., Die neue Weltliteratur und ihre großen Erzähler, C. H. Beck, Monachium 2013.

Lubbock P., The Craft of Fiction, J. Cane, Londyn 1921.

Lynn V., Story Structure Architect. A Writer's Guide to Building Dramatic Situations \& Compelling Characters, Writer's Digest Books, Cincinatti 2005.

Łyczkowska K., Babilońska literatura mądrości, Wydawnictwo Akademickie Dialog, Warszawa 1998.

Łysiak W., Cyrk Nobla literackiego, „Uważam Rze” 2012, nr 39(86).

Magill N. F. (red.), Masterpieces of World Literature, HarperCollins Publishers, Nowy Jork 1989.

Malina-Romańska 0., Pisarze jednej książki, Wydawnictwa Szkolne PWN, Warszawa 2011.

Małyszek T., Literatura niemiecka $w$ teorii i praktyce, Oficyna Wydawnicza ATUT, Wrocław 2007.

Manguel A., Moja historia czytania, Muza, Warszawa 2003.

Matt P. von, Intryga. Teoria i praktyka podstępu w literaturze, Prószyński i Ska, Warszawa 2009.

Morgan A., The World Between Two Covers. Reading the Globe, Liveright Publishing Corporation, Nowy Jork 2015.

Mrożewska A. (red.), Philologische Ostsee-Studien, Wydawnictwo Uczelniane Politechniki Koszalińskiej, Koszalin 2009.

Nabokov V., Wykłady o literaturze, Aletheia, Warszawa 2016.

Osiecka A., Czytadła. Gawędy o lekturach, Prószyński i S-ka, Warszawa 2010. 
Szymon Gębuś - W kierunku pełni. O literaturze światowej...

Oz A., Opowieść się rozpoczyna, Prószyński i S-ka: Warszawa [bdw].

Pamuk 0., Pisarz naiwny i sentymentalny. Wykłady harwardzkie, 2009, Wydawnictwo Literackie, Kraków 2012.

Panza Ch., Gale G., Existentialism for Dummies, Wiley Publishigng Inc., Indianapolis 2008.

Pinker S., Zmierzch przemocy. Lepsza strona naszej natury, Zysk i S-ka, Poznań 2015.

Pound E., ABC czytania, „Teksty. Teoria literatury. Krytyka. Interpretacja” 1981, nr 3 (57).

Powell J., Postmodernism for beginners, Writers and Readres Inc., Danbury 1998.

Przybylski A., Literacki almanach alkoholowy, słowo/obraz terytoria, Gdańsk 2016.

Puchner M., The Written World. The Power of Stories to Shape People, History, Civilization, Random House, Nowy Jork 2017.

Rushdie S., Ojczyzny wyobrażone, Rebis, Poznań 2013.

Rybicka E., Geopoetyka. Przestrzeń i miejsce we współczesnych teoriach i praktykach literackich, Towarzystwo Autorów i Wydawców Prac Naukowych „Universitas”, Kraków 2014.

Sábato E., Pisarz i jego zmory, Wydawnictwo Literackie, Kraków 1987.

Singer P., The Expanding Circle: Ethics, Evolution, and Moral Progress, Princeton University Press, Princeton - Oxford 2011.

Skoczek T. (red.), Historia literatury światowej $w$ dziesięciu tomach, SMS, Bochnia - Kraków - Warszawa 2003-2006.

Solares M., Cómo dibujar una novela, Ediciones Era, Meksyk 2014.

SPARKNOTES 101 Literature. 150 Novels and Plays. One Book, (opracowanie zbiorowe), Spark Publishing, Nowy Jork 2005.

SzymborskaW., Wszystkie lektury nadobowiq̨zkowe, Znak, Kraków 2015.

Tobias R. B., Twenty Master Plots and How to Build Them, Piatkus Books, Londyn 1995.

Tomkowski J., Dzieje literatury powszechnej, Świat Książki, Warszawa 2008.

Tomkowski J., Literatura powszechna według Jana Tomkowskiego, Świat Książki, Warszawa 1997.

Tomkowski J., Zamieszkać w Bibliotece, Dom na Wsi, Ossa 2008.

Turkowska E. (red.), Kształcenie nauczycieli języków obcych, Radomskie Towarzystwo Naukowe, Radom 2013. 
Turkowska E., Literatur auf der Datenautobahn. Zur Rolle der digitalen Literatur im Kommunikations- und Medienzeitalter, Schneider Verlag Hohengehren, Baltmannsweiler 2016.

Wartenberg T. E., Existentialism. A Beginner's Guide, Oneworld Publications, Londyn 2008.

Wasilewski A., 500 zagadek literackich, Wiedza Powszechna, Warszawa 1960.

Wojciszke B., Psychologia miłości. Intymność. Namiętność. Zobowiązanie, Gdańskie Wydawnictwo Psychologiczne, Gdańsk 2009. 